\title{
Sistem Informasi Inventarisasi Peralatan dan Mesin di Rumah Sakit Umum Daerah Sayang Kabupaten Cianjur
}

\author{
Finsa Nurpandi ${ }^{1}$, Diki Gustaman ${ }^{2}$ \\ ${ }^{1,2}$ Program Studi Teknik Informatika \\ Universitas Suryakancana \\ finsa@unsur.ac.id ${ }^{1}$,diki.fg@gmail.com ${ }^{2}$
}

\begin{abstract}
Hospital Sayang Cianjur District in the management of regional property has used SIMDA-BMD. However, the information system has not fulfilled all the needs for the management of regional property, including an inventory of equipment and machinery. Administration of equipment and machinery inventory still uses Microsoft Excel application which is not integrated and takes a long time to process. To make it easier for employees to take inventory, it is necessary to make an inventory information system for equipment and machinery. In making the information system using a system development method based on the waterfall paradigm with the stages of Communication, Planning, Modeling, Construction and Deployment. As for the design method using UML. The programming language uses PHP and MySQL as DBMS. The results of the equipment and machine inventory information system will provide convenience for employees in managing the equipment and machine inventory so that work becomes effective.
\end{abstract}

Keywords: Inventory, Waterfall, UML, PHP, MySQL

\begin{abstract}
Abstrak
RSUD Sayang Kabupaten Cianjur dalam pengelolaan barang milik daerah telah menggunakan SIMDA-BMD. Akan tetapi, sistem informasi tersebut belum memenuhi semua kebutuhan pengelolaan barang milik daerah diantaranya inventarisasi peralatan dan mesin. Administrasi inventarisasi peralatan dan mesin masih menggunakan aplikasi Microsoft Excel yang tidak terintegrasi dan memerlukan waktu cukup lama dalam pengerjaannya. Untuk mempermudah pegawai dalam inventarisasi perlu dibuat sistem informasi inventarisasi peralatan dan mesin. Dalam pembuatan sistem informasi tersebut menggunakan metoda pengembangan sistem berdasarkan paradigma waterfall dengan tahapan Communication, Planning, Modeling, Construction dan Deployment. Sedangkan untuk metoda perancangan menggunakan UML. Bahasa pemrograman menggunakan PHP dan MySql sebagai DBMS. Hasil dari sistem informasi inventarisasi peralatan dan mesin akan memberikan kemudahan bagi pegawai dalam mengelola inventarisasi peralatan dan mesin sehingga pekerjaan menjadi efektif.
\end{abstract}

Kata Kunci : Inventarisasi, Peralatan dan Mesin, Waterfall, UML, Sistem Informasi

\section{PENDAHULUAN}

\subsection{Latar Belakang Masalah}

Sistem informasi mencakup sejumlah komponen (manusia, komputer, teknologi informasi), ada sesuatu yang diproses (data menjadi informasi), dan dimaksudkan untuk mencapai suatu sasaran atau tujuan [1] Inventarisasi adalah kegiatan untuk melakukan pendataan, pencatatan, dan pelaporan hasil pendataan barang milik daerah [2]. Peralatan dan Mesin merupakan salah satu jenis barang milik daerah berupa aset tetap yang mencakup mesinmesin dan kendaraan bermotor, alat elektronik, inventaris kantor, dan peralatan lainnya yang nilainya signifikan dan masa manfaatnya lebih dari 12 (dua belas) bulan dan dalam kondisi siap pakai [3]. Rumah Sakit Umum Daerah (RSUD) Sayang merupakan Perangkat Daerah Pemerintah Kabupaten Cianjur yang bergerak dalam bidang pelayanan kesehatan bagi masyarakat.

Pemerintah Kabupaten Cianjur telah menerapkan Sistem Informasi Manajemen Daerah - Barang Milik Daerah (SIMDA-BMD) untuk menunjang dalam pengelolaan barang milik daerah. Akan tetapi, sistem informasi tersebut belum memenuhi semua kebutuhan pengelolaan barang milik daerah diantaranya inventarisasi peralatan dan mesin. Inventarisasi peralatan dan mesin, mulai dari pembuatan kertas kerja inventarisasi menggunakan Microsoft Excel yang memuat daftar dan foto barang per ruangan per unit kerja. Data kertas kerja dan lokasi barang di ruangan banyak perbedaannya karena Penanggunjawab Ruangan kesulitan menyampaikan laporan setiap ada perubahan atau perpindahan barang sehingga pelaksanaan inventarisasi lebih lama. Pencatatan dan pembuatan laporan hasil inventarisasi menggunakan Microsoft Excel. Proses administrasi menggunakan Microsoft Excel, yang bukan merupakan aplikasi khusus, sehingga tidak dapat terintegrasi dan memerlukan waktu cukup lama dalam pengerjaannya yang mengakibatkan kinerja menjadi tidak efektif. 


\subsection{Maksud dan Tujuan}

Maksud penelitian ini adalah menyelesaikan permasalahan dalam inventarisasi peralatan dan mesin di RSUD Sayang Kabupaten Cianjur dengan membangun sebuah sistem informasi.

Tujuan dari penelitian ini adalah sebagai berikut :

a. Mempermudah pegawai dalam pembuatan kertas kerja inventarisasi peralatan dan mesin;

b. Mempermudah pegawai dalam pelaksanaan inventarisasi peralatan dan mesin di lapangan/ruangan;

c. Mempermudah pegawai dalam pencatatan hasil inventarisasi peralatan dan mesin;

d. Mempermudah pegawai dalam pelaporan hasil inventarisasi peralatan dan mesin kepada pimpinan;

e. Menyimpan riwayat inventarisasi peralatan dan mesin;

f. Membuat pekerjaan pegawai menjadi lebih efektif.

\subsection{Tinjauan Pustaka}

\subsubsection{Inventarisasi}

Inventarisasi adalah kegiatan untuk melakukan pendataan, pencatatan, dan pelaporan hasil pendataan barang milik daerah. Pengguna Barang melakukan inventarisasi barang milik daerah paling sedikit 1 (satu) kali dalam 5 (lima) tahun. Dalam hal barang milik daerah berupa persediaan dan konstruksi dalam pengerjaan, inventarisasi dilakukan oleh Pengguna Barang setiap tahun. Pengguna Barang menyampaikan laporan hasil inventarisasi kepada Pengelola Barang paling lama 3 (tiga) bulan setelah selesainya inventarisasi [2].

Pelaksanaan inventarisasi [4]:

a. Membuat peta/denah kasar atas bangunan beserta ruangan yang ada di dalam bangunan dan gedung tersebut kemudian diberi nomor dan nama penanggung jawab ruangan tersebut.

b. Pencacahan/cek fisik Barang Milik Daerah Unit Kerja menurut ruangan masing-masing dengan menghitung jumlah barang sekaligus memberi label sementara untuk BMD yang sudah dihitung untuk menghindari doble counting (pengakuan ganda), meneliti kondisi barang (baik, kurang baik atau rusak berat) selanjutnya melengkapi Kertas Kerja Inventarisasi (KKI) berdasarkan letak barang, kondisi barang, pemanfaatan dan nama personil yang menggunakan barang.

c. Meneliti, mencocokkan, dan mengoreksi data barang milik daerah yang tercantum di Kertas Kerja Inventarisasi (KKI) sesuai hasil pencacahan barang yang sebenarnya

d. Pelaporan Hasil Inventarisasi

1. Menyusun Rekapitulasi Laporan Hasil Inventarisasi berdasarkan Kertas Kerja Inventarisasi (KKI), dengan kriteria kondisi :

i. Barang Baik;

ii. Barang Kurang Baik;

iii. Barang Rusak Berat; dan

iv. Barang Tidak Diketemukan.

2. Membuat Berita Acara Inventarisasi

3. Menyampaikan Rekapitulasi Laporan Hasil Inventarisasi kepada Pembantu Pengelola Barang

\section{Peralatan dan Mesin}

Menurut Kamus Besar Bahasa Indonesia, peralatan kantor berarti sesuatu yang dapat dipakai sebagai alat dalam mencapai maksud dan tujuan. Peralatan kantor adalah suatu sarana dan prasarana yang dapat memperlancar atau mempercepat pelaksanaan pekerjaan kantor [5]. Mesin kantor adalah sebuah alat yang dipergunakan untuk menghimpun, mencatat dan mengolah bahan-bahan, data ataupun keterangan dalam suatu pekerjaan tata usaha yang cara kerjanya bersifat mekanik, elektrik dan magnetik [5]. Peralatan dan Mesin adalah aset tetap yang mencakup mesin-mesin dan kendaraan bermotor, alat elektronik, inventaris kantor, dan peralatan lainnya yang nilainya signifikan dan masa manfaatnya lebih dari 12 (dua belas) bulan dan dalam kondisi siap pakai [3].

\subsubsection{Unified Modeling Language (UML)}

Unified Modeling Language (UML) merupakan diagram sistem menggunakan orientasi objek (object oriented) dalam analisis dan perancangan sistem. UML saat ini menjadi standar dalam berbagai tipe solusi piranti lunak dalam pengembangan sistem. Unified berarti gabungan dari berbagai bahasa pemodelan berorientasi objek yang telah ada sebelumnya. Sehingga bentuk diagram yang tergabung dalam UML pun beragam jumlahnya. UML merupakan sebuah bahasa yang telah menjadi standar dalam industri untuk visualisasi, merancang dan mendokumentasikan sistem piranti lunak. UML mendefinisikan notasi dan syntax/semantik [6][7].

UML terdapat beberapa Diagram yaitu:

a. Use Case Diagram

Use Case Diagram menggambarkan fungsionalitas yang diharapkan dari sebuah sistem. Yang ditekankan adalah "apa" yang diperbuat sistem, dan bukan "bagaimana". Sebuah use case mempresentasikan sebuah interaksi antara aktor dengan sistem.

b. Class Diagram

Class diagram menunjukkan properti dan operasi sebuah class dan batasan-batasan yang terdapat dalam hubungan objek tersebut. UML menggunakan istilah fitur sebagai istilah umum yang meliputi properti dan operasi sebuah class.

c. Swimlane Diagram/Activity Diagram

Swimlane Diagram/Activity Diagram adalah suatu ilustrasi sederhana akan apa yang terjadi dalam aliran kerja, aktivitas apa yang dapat dilakukan secara paralel, dan apakah terdapat jalur alternatif dalam aliran kerja.

\section{d. Sequence Diagram}

Sequence Diagram menggambarkan interaksi antar objek di dalam dan di sekitar sistem (termasuk pengguna, display, dan sebagainya) berupa message yang digambarkan terhadap waktu.

\subsubsection{Entity Relationship Diagram (ERD)}

Entity Relationship Diagram (ERD) merupakan teknik grafis yang digunakan untuk menggambarkan skema database. ER diagrams mengilustrasikan struktur logik atas database dengan memperhatikan entitas-entitas dalam sistem. 


\subsubsection{Pengujian Black Box}

Metode ujicoba black box memfokuskan pada keperluan fungsional dari software. Karna itu ujicoba black box memungkinkan pengembang software untuk membuat himpunan kondisi input yang akan melatih seluruh syarat-syarat fungsional suatu program. Ujicoba black box berusaha untuk menemukan kesalahan dalam beberapa kategori, diantaranya :

a) Fungsi-fungsi yang salah atau hilang

b) Kesalahan interface

c) Kesalahan dalam struktur data atau akses database eksternal

d) Kesalahan performa

e) Kesalahan inisialisasi dan terminasi.

Kasus uji yang memberitahukan sesuatu tentang keberadaan atau tidaknya suatu jenis kesalahan, dari pada kesalahan yang terhubung hanya dengan suatu ujicoba yang spesifik.

\section{METODE PENELITIAN}

Metode perancangan rekayasa perangkat lunak yang digunakan adalah paradigma waterfall. Metode ini terdiri dari 5 tahap yaitu Communication, Planning, Modeling, Construction dan Deployment.

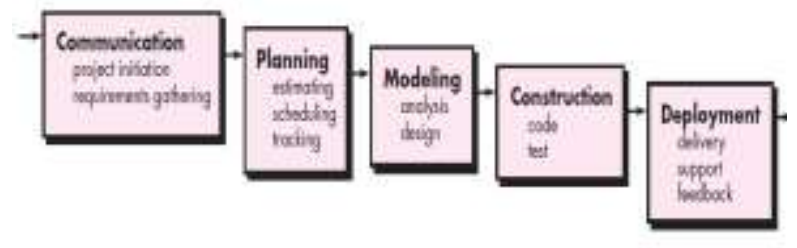

Gambar 1 : Model waterfall [8]

Berikut tahapan-tahapan dalam metode waterfall :

a. Communication: Peneliti melakukan survey dan komunikasi dengan melakukan wawancara ke Sub Bagian Kerumahtanggaan dan Perlengkapan RSUD Sayang Kabupaten Cianjur.

b. Planning: Peneliti melakukan perencanaan sistem yang akan dibuat sesuai dengan keinginan pengguna dalam pembuatan sistem informasi.

c. Modelling: Peneliti melakukan analisis sistem yang akan dibuat meliputi Analysis Modeling dan Design Modeling. Pada Analysis Modeling meliputi Scenario-Based Modelling dengan membuat Use Case Diagram dan Activity Diagram atau Swimlane Diagram, Data Modelling dengan membuat Class Diagram dan Entity Relationship Diagram serta Behavioral Modeling dengan membuat Sequence Diagram. Pada Design Modeling meliputi Architectural Design dengan membuat struktur menu dan User Interface Design dengan membuat desain tampilan sistem informasi yang akan dibuat.

d. Construction: Peneliti membuat sistem informasi sesuai dengan perencanaan dan analisis dengan menggunakan bahasa pemrograman PHP serta melakukan testing.

e. Deployment: Setelah selesai pengujian dan evaluasi selanjutnya Peneliti memberikan produk berupa sistem informasi jadi kepada RSUD Sayang

Kabupaten Cianjur.

\section{HASIL PENELITIAN}

\subsection{Analisis Kebutuhan Fungsional}

Kebutuhan fungsional menjelaskan mengenai proses-proses apa saja yang akan dilakukan oleh sistem. Deskripsi dari kebutuhan aktivitas-aktivitas dan layananlayanan yang harus disediakan oleh sistem, kebutuhan fungsional sistem menggambarkan layanan secara detail. Berikut adalah fungsi atau modul yang dibutuhkan oleh sistem yang nantinya akan digunakan oleh pengguna.

\begin{tabular}{|c|c|c|}
\hline No & Modul & Keterangan \\
\hline 1 & Login & Otentikasi masuk sistem \\
\hline 2 & Mengelola Akun & $\begin{array}{l}\text { Melihat profil, mengubah } \\
\text { profil dan mengubah } \\
\text { password }\end{array}$ \\
\hline 3 & $\begin{array}{l}\text { Mengelola } \\
\text { Pengguna }\end{array}$ & $\begin{array}{l}\text { Melihat, menambah, } \\
\text { mengubah, dan } \\
\text { menghapus pengguna }\end{array}$ \\
\hline 4 & $\begin{array}{l}\text { Mengelola Master } \\
\text { Satuan }\end{array}$ & $\begin{array}{l}\text { Melihat, menambah, } \\
\text { mengubah, } \\
\text { menghapus satuan }\end{array}$ \\
\hline 5 & $\begin{array}{l}\text { Mengelola Master } \\
\text { Sumber Dana }\end{array}$ & $\begin{array}{lr}\text { Melihat, } & \text { menambah, } \\
\text { mengubah, } & \text { dan } \\
\text { menghapus } & \text { sumber dana }\end{array}$ \\
\hline 6 & $\begin{array}{l}\text { Mengelola Master } \\
\text { Cara Perolehan }\end{array}$ & $\begin{array}{lr}\text { Melihat, menambah, } \\
\text { mengubah, } \\
\text { menghapus cara perolehan }\end{array}$ \\
\hline 7 & $\begin{array}{l}\text { Mengelola Master } \\
\text { Status Inventarisasi }\end{array}$ & $\begin{array}{l}\text { Melihat, menambah, } \\
\text { mengubah, danmenghapus } \\
\text { status inventarisasi }\end{array}$ \\
\hline 8 & $\begin{array}{l}\text { Mengelola Master } \\
\text { Barang }\end{array}$ & $\begin{array}{l}\text { Melihat, menambah, } \\
\text { mengubah, menghapus, } \\
\text { dan mencari barang }\end{array}$ \\
\hline 9 & $\begin{array}{l}\text { Mengelola Master } \\
\text { Pegawai }\end{array}$ & $\begin{array}{l}\text { Melihat, menambah, } \\
\text { mengubah, menghapus, } \\
\text { dan mencari pegawai }\end{array}$ \\
\hline 10 & $\begin{array}{ll}\text { Mengelola } & \text { Master } \\
\text { Unit Kerja } & \end{array}$ & $\begin{array}{l}\text { Melihat, menambah, } \\
\text { mengubah, menghapus, } \\
\text { dan mencari unit kerja }\end{array}$ \\
\hline 11 & $\begin{array}{l}\text { Mengelola Master } \\
\text { Gedung }\end{array}$ & $\begin{array}{l}\text { Melihat, menambah, } \\
\text { mengubah, menghapus, } \\
\text { dan mencari gedung }\end{array}$ \\
\hline 12 & $\begin{array}{l}\text { Mengelola Master } \\
\text { Ruangan }\end{array}$ & $\begin{array}{l}\text { Melihat, menambah, } \\
\text { mengubah, menghapus, } \\
\text { dan mencari ruangan }\end{array}$ \\
\hline 13 & Mengelola KIB & $\begin{array}{l}\text { Melihat, menambah, } \\
\text { mengubah, menyalin, } \\
\text { menghapus, dan mencari } \\
\text { KIB peralatan dan mesin }\end{array}$ \\
\hline 14 & $\begin{array}{l}\text { Mengelola } \\
\text { Persetujuan KIB }\end{array}$ & $\begin{array}{l}\text { Melihat, mencari, } \\
\text { menyetujui r dan } \\
\text { membatalkan persetujuan } \\
\text { data KIB peralatan dan } \\
\text { mesin }\end{array}$ \\
\hline 15 & Memverifikasi KIB & $\begin{array}{lr}\text { Melihat, } & \text { mencari, } \\
\text { memverifikasi } & \text { dan } \\
\text { membatalkan } & \text { verifikasi }\end{array}$ \\
\hline
\end{tabular}


DOI : $10.35194 / m j i . v 13 i 2.1733$

\begin{tabular}{|c|c|c|}
\hline No & Modul & Keterangan \\
\hline & & $\begin{array}{l}\text { data KIB peralatan dan } \\
\text { mesin }\end{array}$ \\
\hline 16 & Mengelola KIR & $\begin{array}{l}\text { Memperbaharui data } \\
\text { inventarisasi (kondisi dan } \\
\text { keberadaan), menambah } \\
\text { dan menghapus peralatan } \\
\text { dan mesin di ruangan }\end{array}$ \\
\hline 17 & $\begin{array}{l}\text { Mengelola } \\
\text { Persetujuan KIR }\end{array}$ & $\begin{array}{l}\text { Melihat, mencari, } \\
\text { menyetujui r dan } \\
\text { membatalkan persetujuan } \\
\text { data KIR peralatan dan } \\
\text { mesin }\end{array}$ \\
\hline 18 & Memverifikasi KIB & $\begin{array}{lr}\text { Melihat, } & \text { mencari, } \\
\text { memverifikasi } & \text { dan } \\
\text { membatalkan verifikasi } \\
\text { data KIR peralatan dan } \\
\text { mesin }\end{array}$ \\
\hline 19 & $\begin{array}{l}\text { Mengelola Laporan } \\
\text { Inventarisasi }\end{array}$ & $\begin{array}{l}\text { Melihat dan mencetak } \\
\text { Berita Acara, daftar hasil } \\
\text { inventarisasi, kertas kerja } \\
\text { inventarisasi dan KIR }\end{array}$ \\
\hline 20 & $\begin{array}{l}\text { Melihat Rekap } \\
\text { Inventarisasi }\end{array}$ & $\begin{array}{l}\text { Melihat/monitoring rekap } \\
\text { inventarisasi peralatan dan } \\
\text { mesin }\end{array}$ \\
\hline 21 & Logout & Keluar sistem \\
\hline
\end{tabular}

\subsection{Analisis Pengguna}

Analisis pengguna mendefinisikan siapa saja yang menggunakan sistem dan apa saja yang dapat dilakukan oleh pengguna di dalam sistem. Sistem yang dibangun memiliki 6 (enam) pengguna yaitu :

\begin{tabular}{|c|l|l|}
\hline No & \multicolumn{1}{|c|}{ Pengguna } & \multicolumn{1}{|c|}{ Keterangan } \\
\hline 1 & Admin & $\begin{array}{l}\text { Orang yang mengelola } \\
\text { data-data master. }\end{array}$ \\
\hline 2 & $\begin{array}{l}\text { Penanggungjawab } \\
\text { Ruangan (PJR) }\end{array}$ & $\begin{array}{l}\text { Orang yang mengelola } \\
\text { data inventarisasi } \\
\text { peralatan dan mesin di } \\
\text { ruangannya. }\end{array}$ \\
\hline 3 & $\begin{array}{l}\text { Pengelola } \\
\text { Pemanfaatan } \\
\text { BMD (PPBMD) }\end{array}$ & $\begin{array}{l}\text { Orang yang melaksanakan } \\
\text { pengelolaan dan } \\
\text { inventaris dan } \\
\text { inventarisasi peralatan dan } \\
\text { mesin serta laporan. }\end{array}$ \\
\hline 4 & $\begin{array}{l}\text { Pengurus Barang } \\
\text { Pengguna (PBP) }\end{array}$ & $\begin{array}{l}\text { Orang yang mengelola } \\
\text { data persetujuan KIB dan } \\
\text { KIR, dan laporan. }\end{array}$ \\
\hline 5 & $\begin{array}{l}\text { Pejabat } \\
\text { Penatausahaan } \\
\text { Pengguna Barang } \\
\text { (P3B) }\end{array}$ & $\begin{array}{l}\text { Orang yang mengelola } \\
\text { data verifikasi KIB dan } \\
\text { KIR. }\end{array}$ \\
\hline 6 & $\begin{array}{l}\text { Pengguna Barang } \\
\text { (PB) }\end{array}$ & $\begin{array}{l}\text { Orang yang memonitoring } \\
\text { rekap inventarisasi. }\end{array}$ \\
\hline
\end{tabular}

TABEL 2 : Pengguna

\subsection{Perancangan Sistem}

Perancangan sistem dilakukan dengan membuat pemodelan sistem dengan menggunakan UML sebagai penggambaran, perencanaan dan pembuatan sistem yang akan dibangun. UML yang digunakan yaitu Use Case Diagram, Swimlane Diagram, Class Diagram dan Sequence Diagram.

\subsubsection{Use Case Diagram}

Use case diagram memperlihatkan tiga aspek sistem yaitu aktor, use case, dan lingkup sistem. Memperlihatkan hubungan antara aktor dan fungsi yang dapat dilakukan oleh aktor dalam ruang lingkup sistem. Berikut gambar use case diagram sistem yang akan dibangun. 


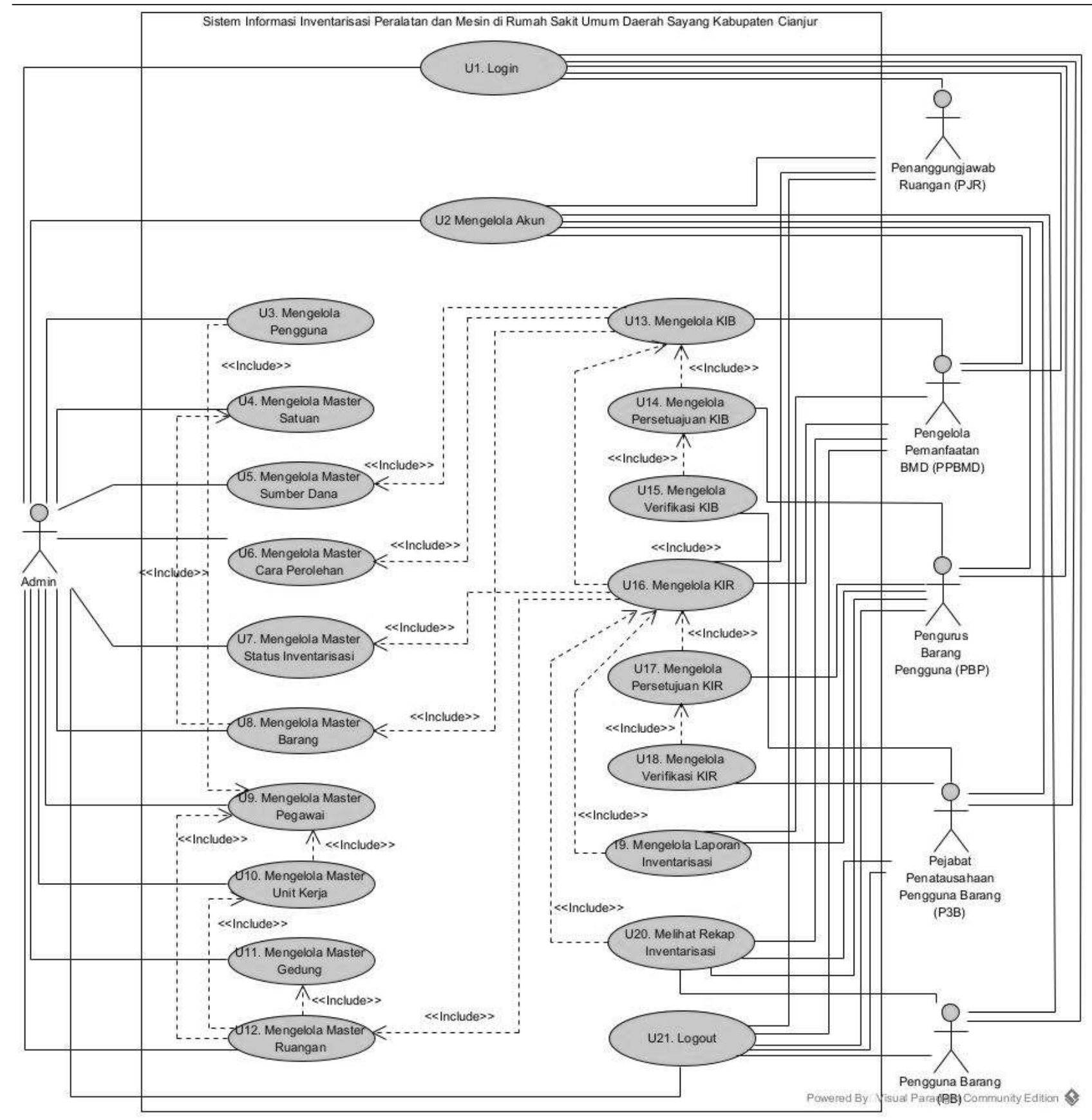

Gambar 2 : Use case diagram

\subsubsection{Swimlane Diagram}

Berikut ini adalah swimlane diagram dari sistem yang akan dibangun :

1) Login

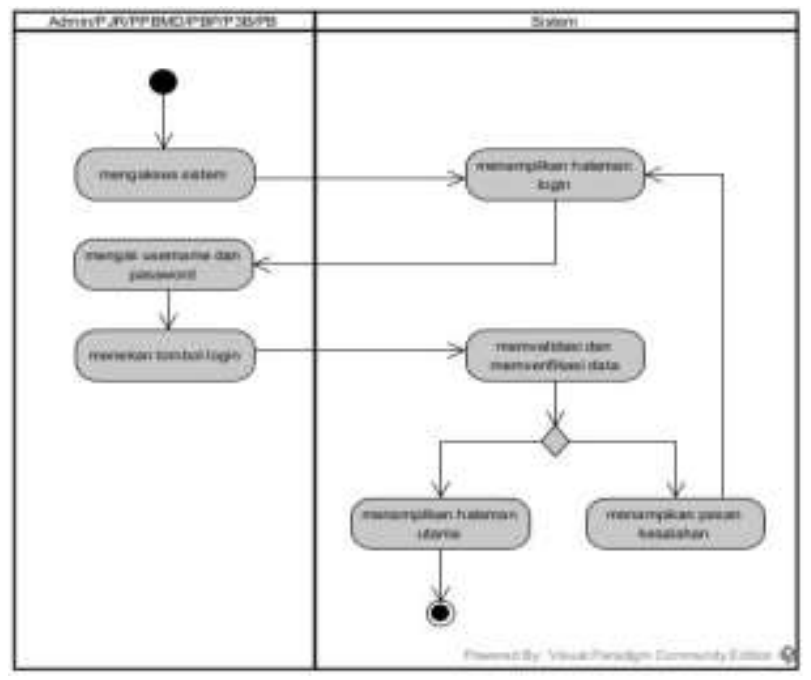

Gambar 3 : Swimlane diagram login 


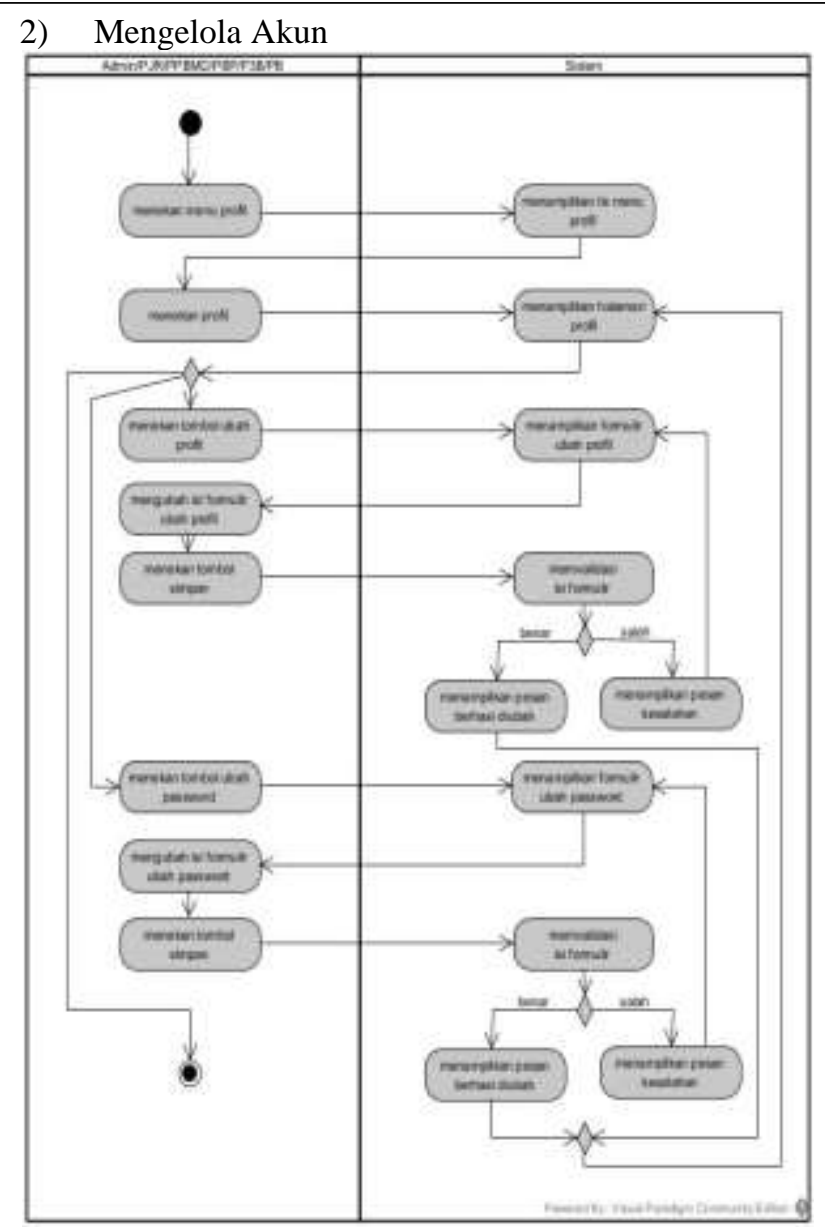

Gambar 4 : Swimlane diagram mengelola akun

3) Mengelola Pengguna

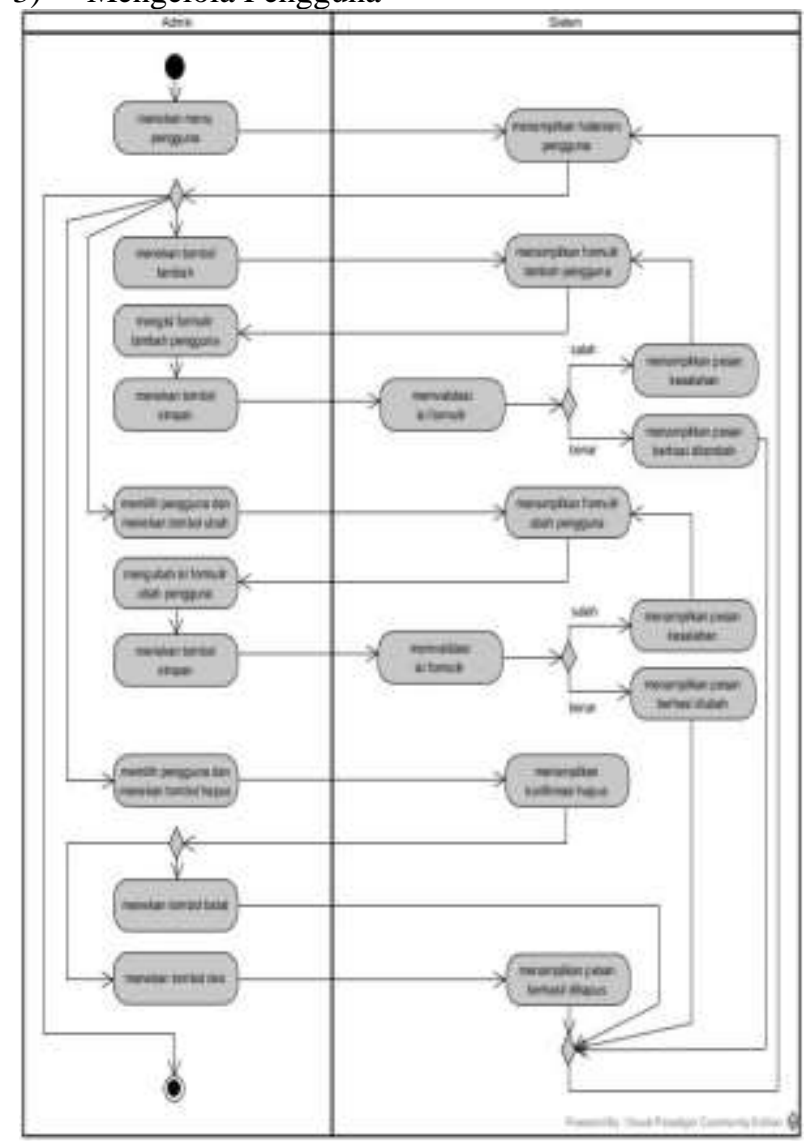

Gambar 5 : Swimlane diagram mengelola pengguna
4) Mengelola Master Satuan

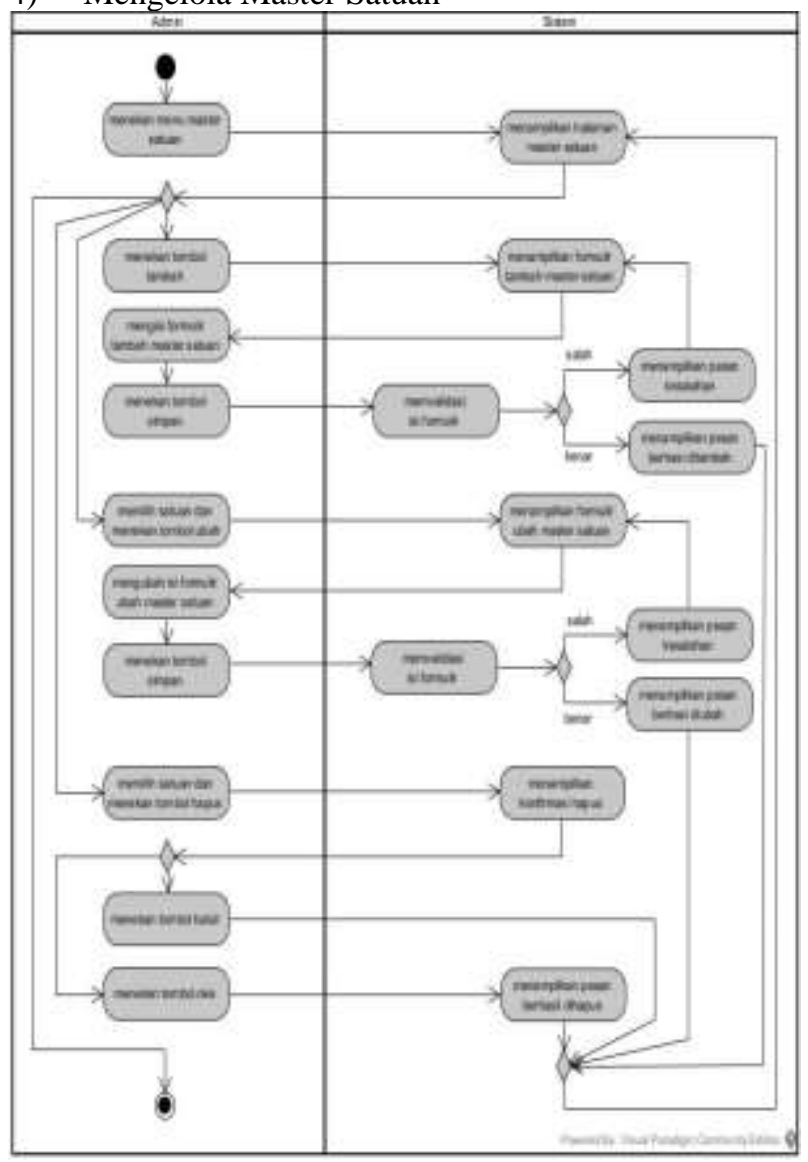

Gambar 6 : Swimlane diagram mengelola master satuan

5) Mengelola Master Sumber Dana

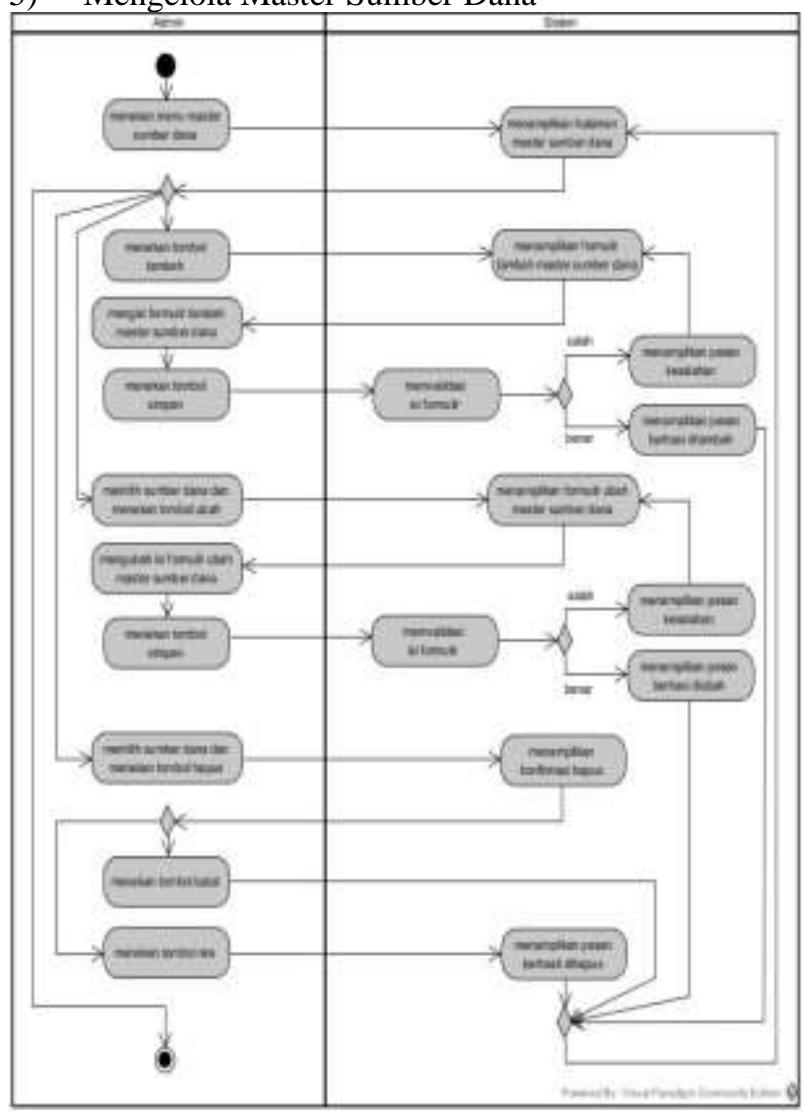

Gambar 7 : Swimlane diagram mengelola master sumber dana 
MJI Vol.X, No.X, [nama_bulan] 20XX, hlm. xxx-xxx

6) Mengelola Master Cara Perolehan

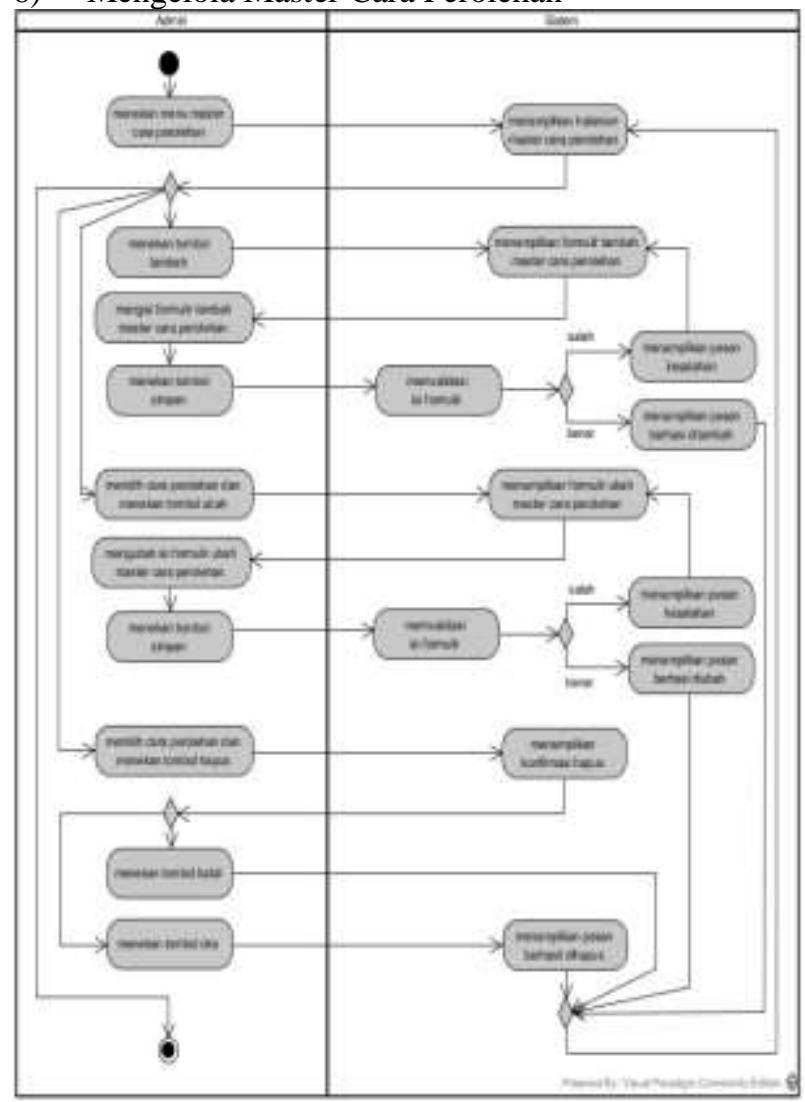

Gambar 8 : Swimlane diagram mengelola master cara perolehan

7) Mengelola Master Status Inventarisasi

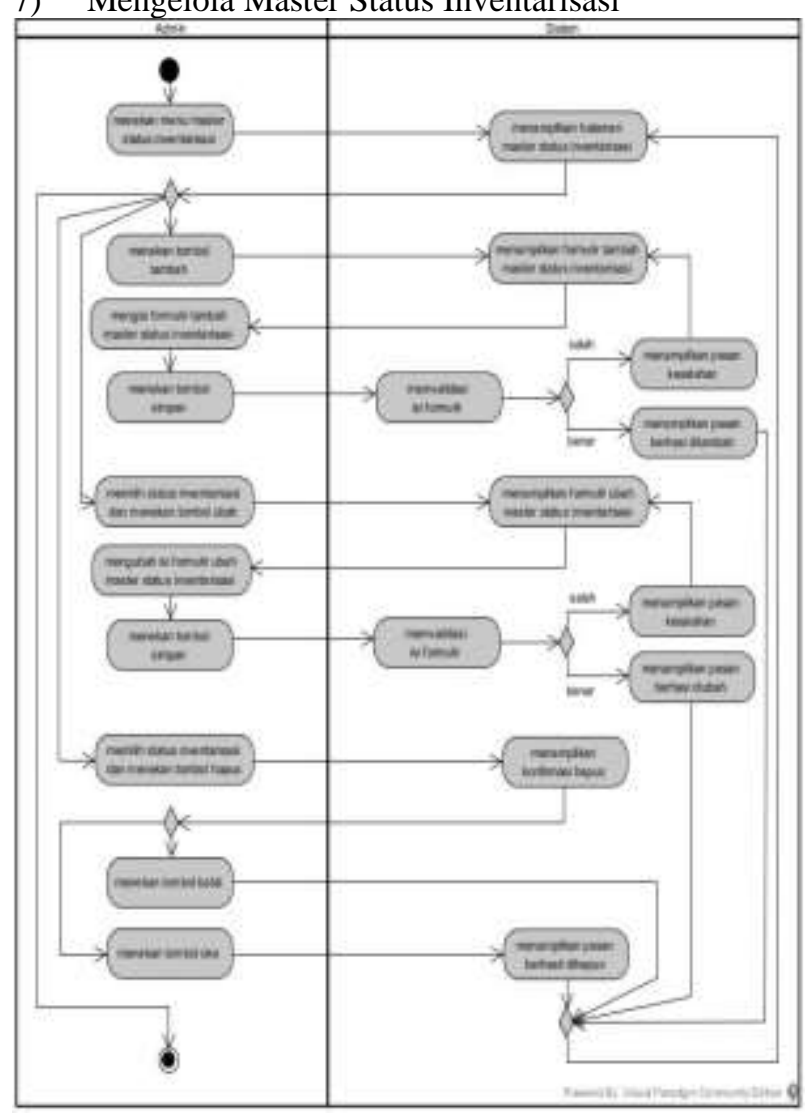

Gambar 9 : Swimlane diagram mengelola master status inventarisasi

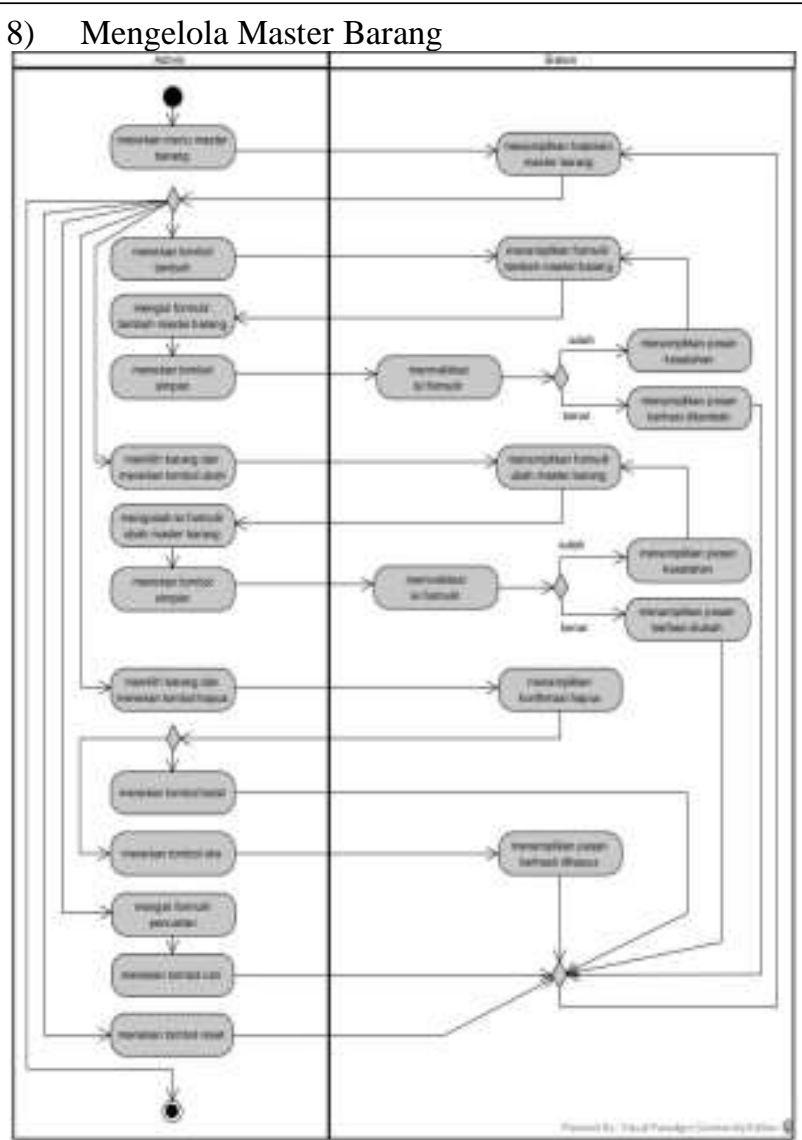

Gambar 10 : Swimlane diagram mengelola master barang

9) Mengelola Master Pegawai

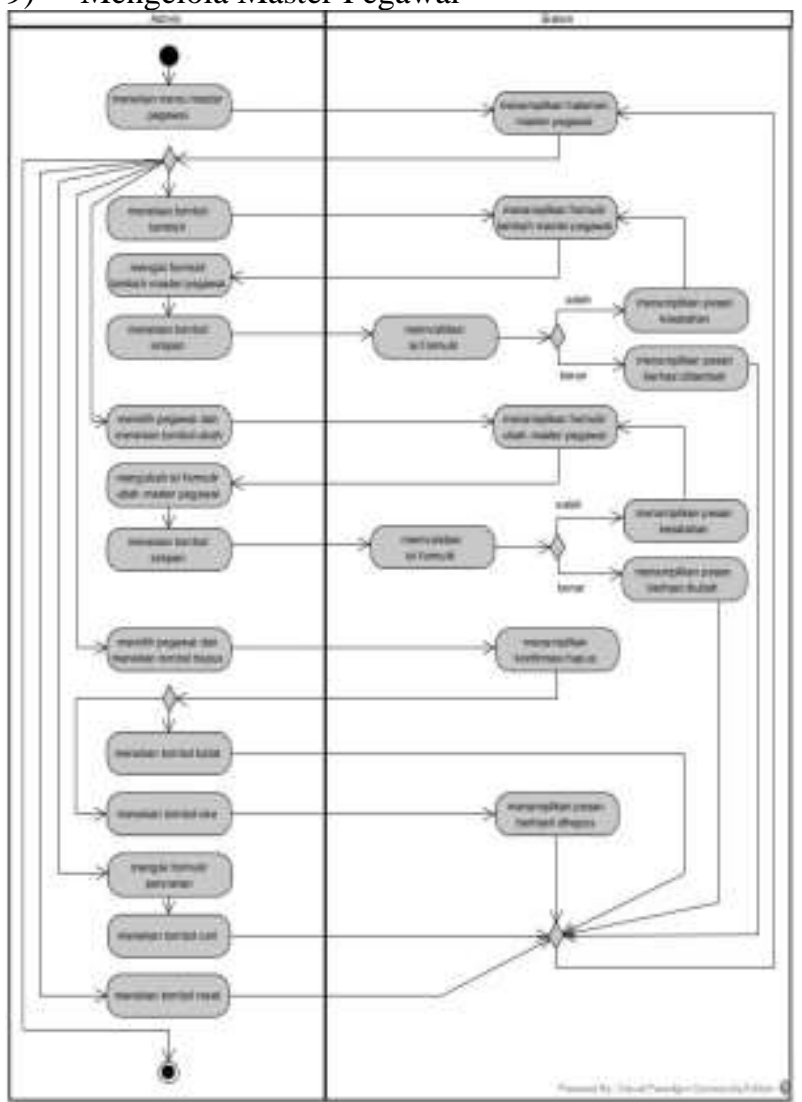

Gambar 11 : Swimlane diagram mengelola master pegawai 


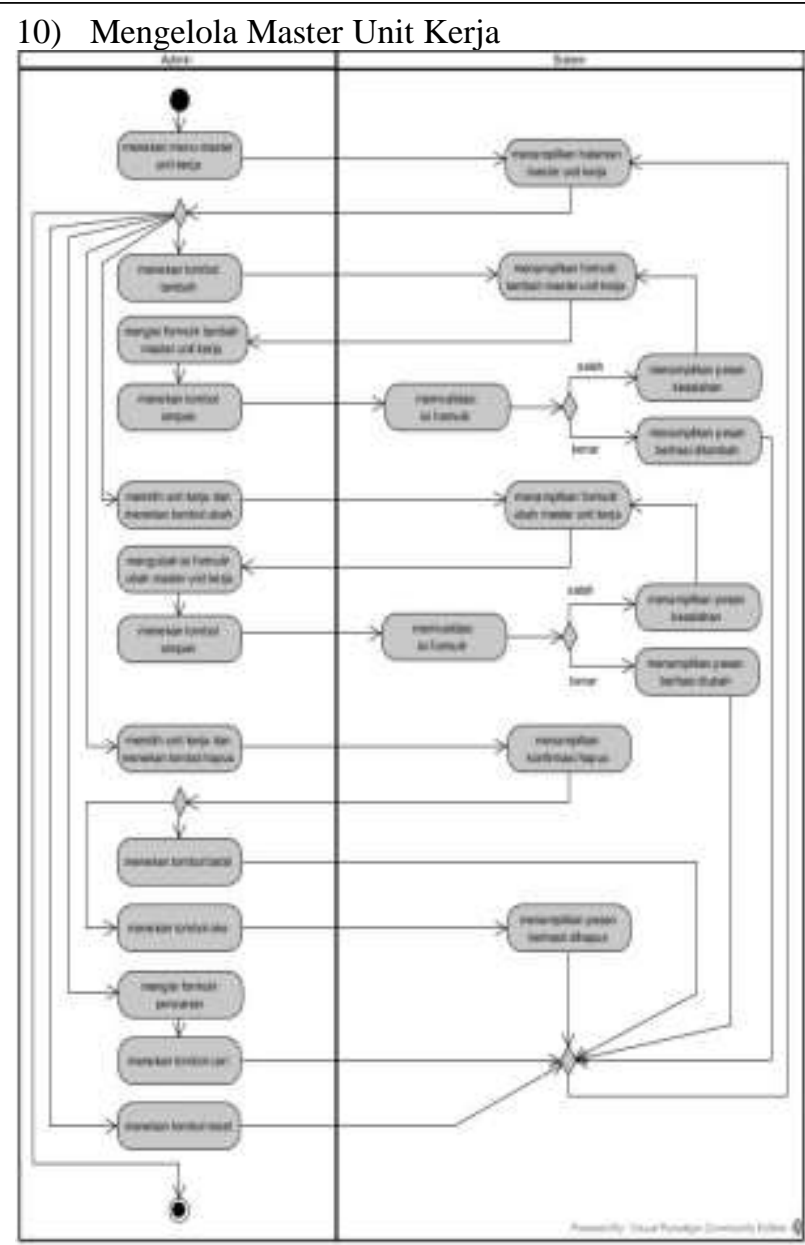

Gambar 12 : Swimlane diagram mengelola master unit kerja

11) Mengelola Master Gedung

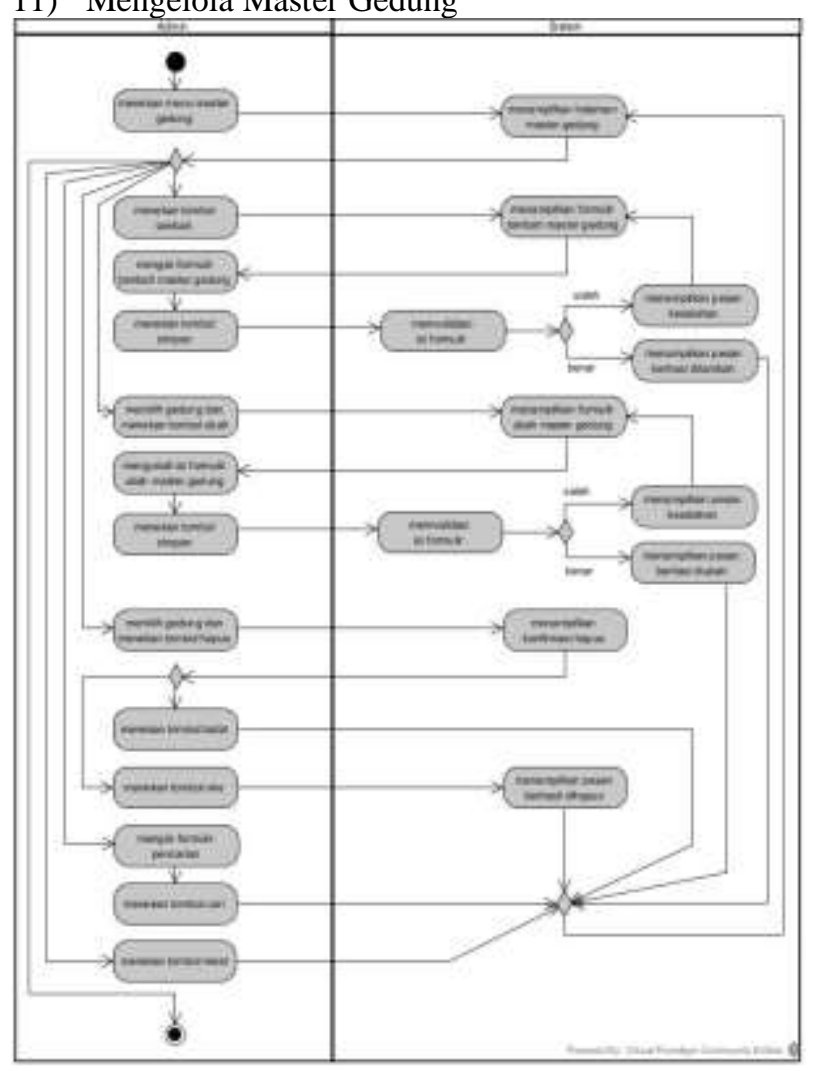

Gambar 13 : Swimlane diagram mengelola master gedung

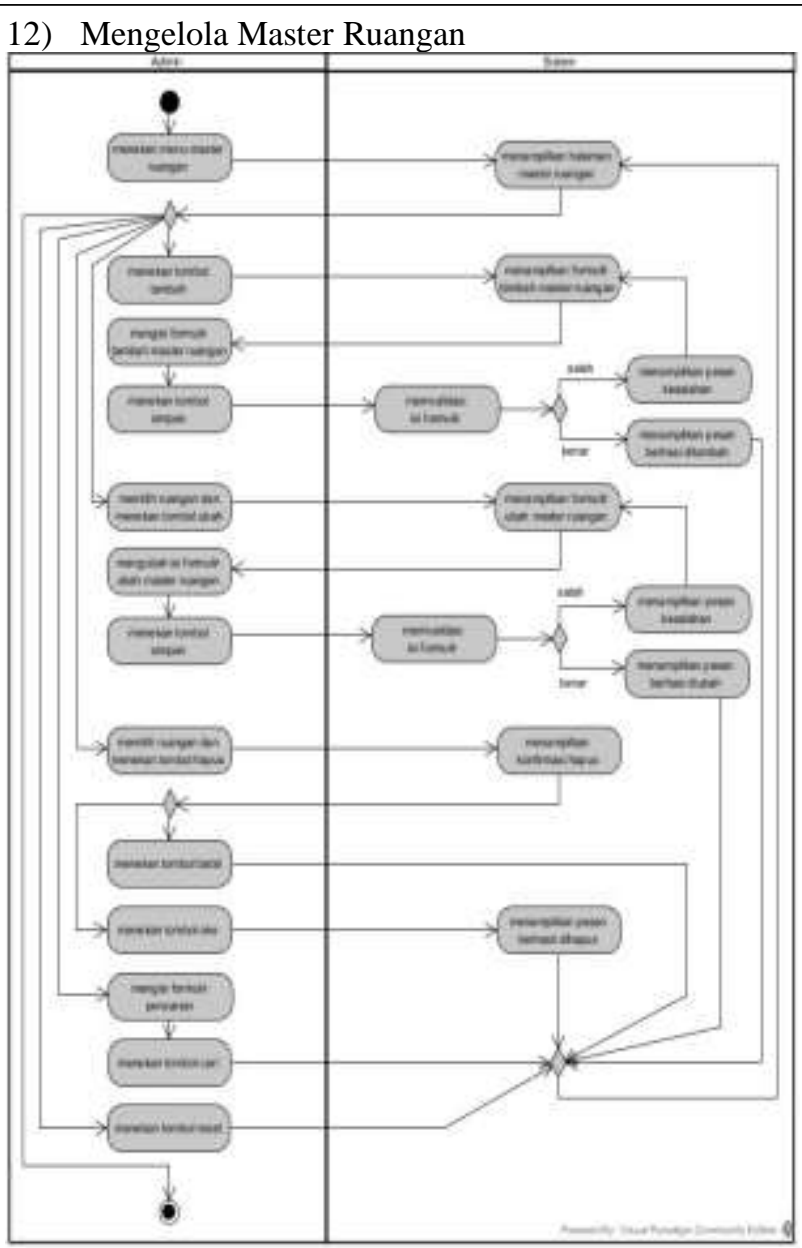

Gambar 14 : Swimlane diagram mengelola master ruangan

13) Mengelola KIB

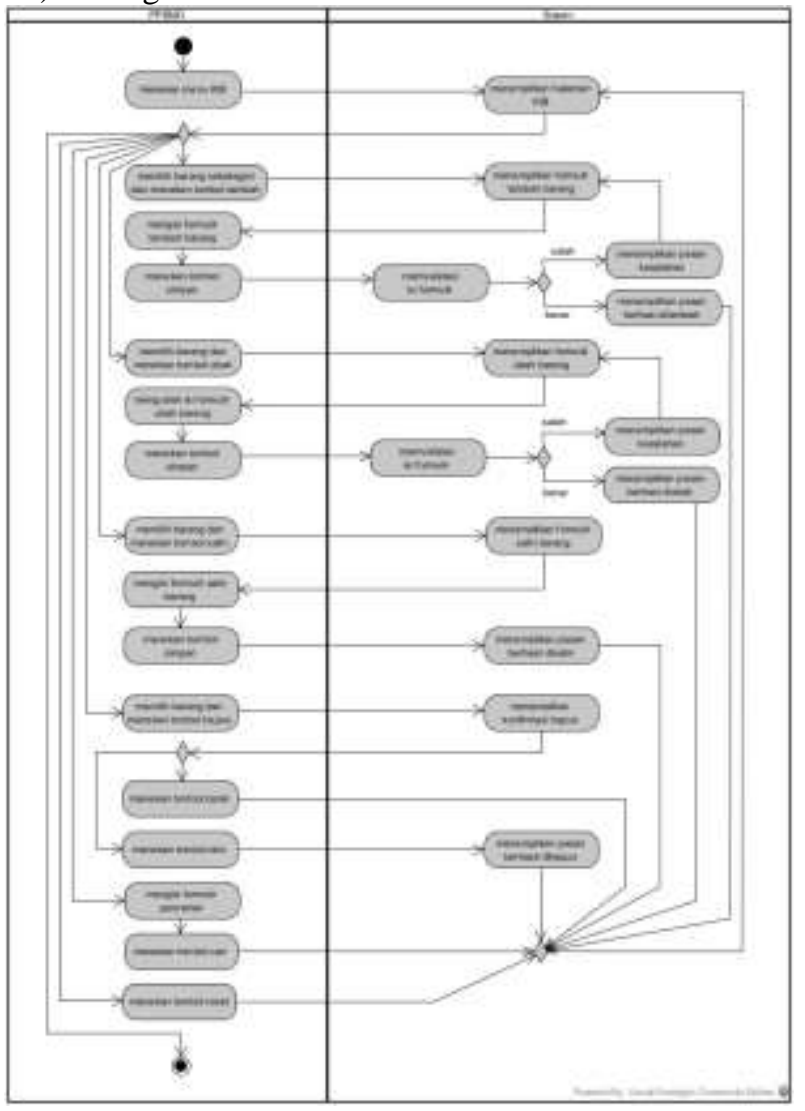

Gambar 15 : Swimlane diagram mengelola KIB 
MJI Vol.X, No.X, [nama_bulan] 20XX, hlm. xxx-xxx

\section{4) Mengelola Persetujuan KIB}

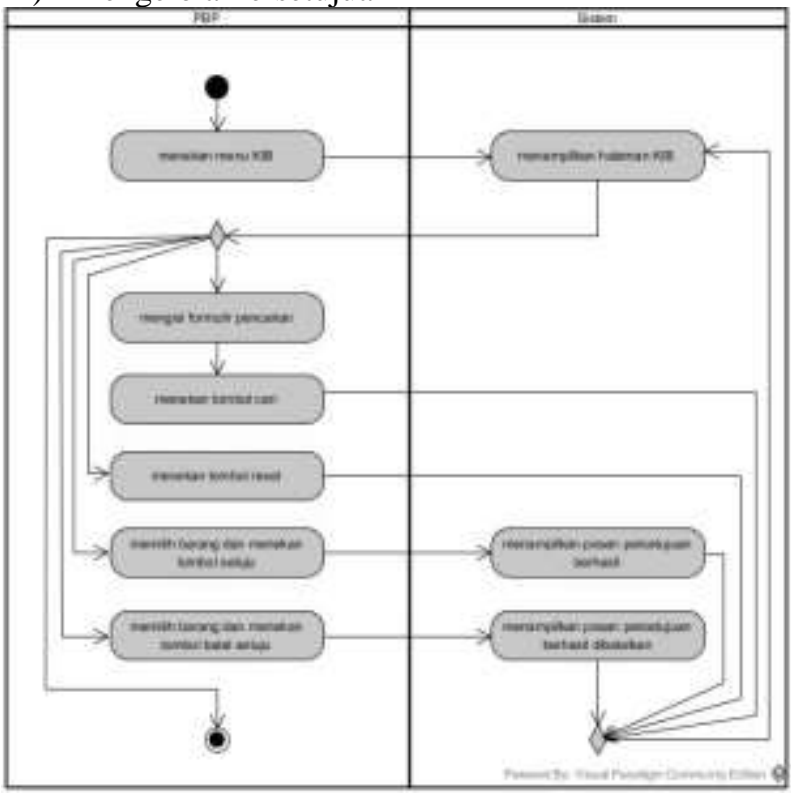

Gambar $16:$ Swimlane diagram mengelola persetujuan KIB

15) Mengelola Verifikasi KIB

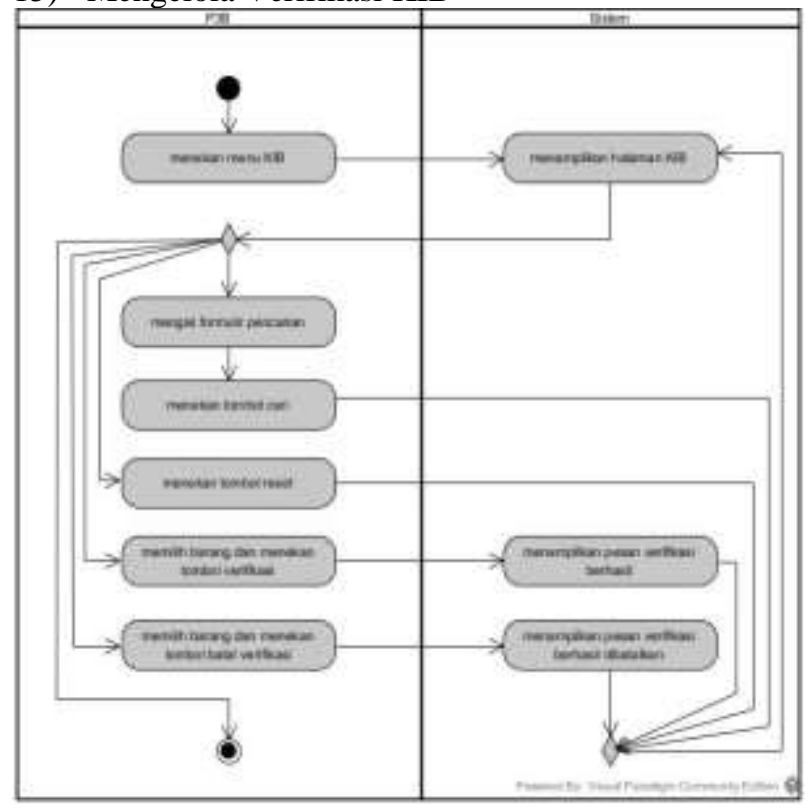

Gambar 17 : Swimlane diagram mengelola verifikasi KIB

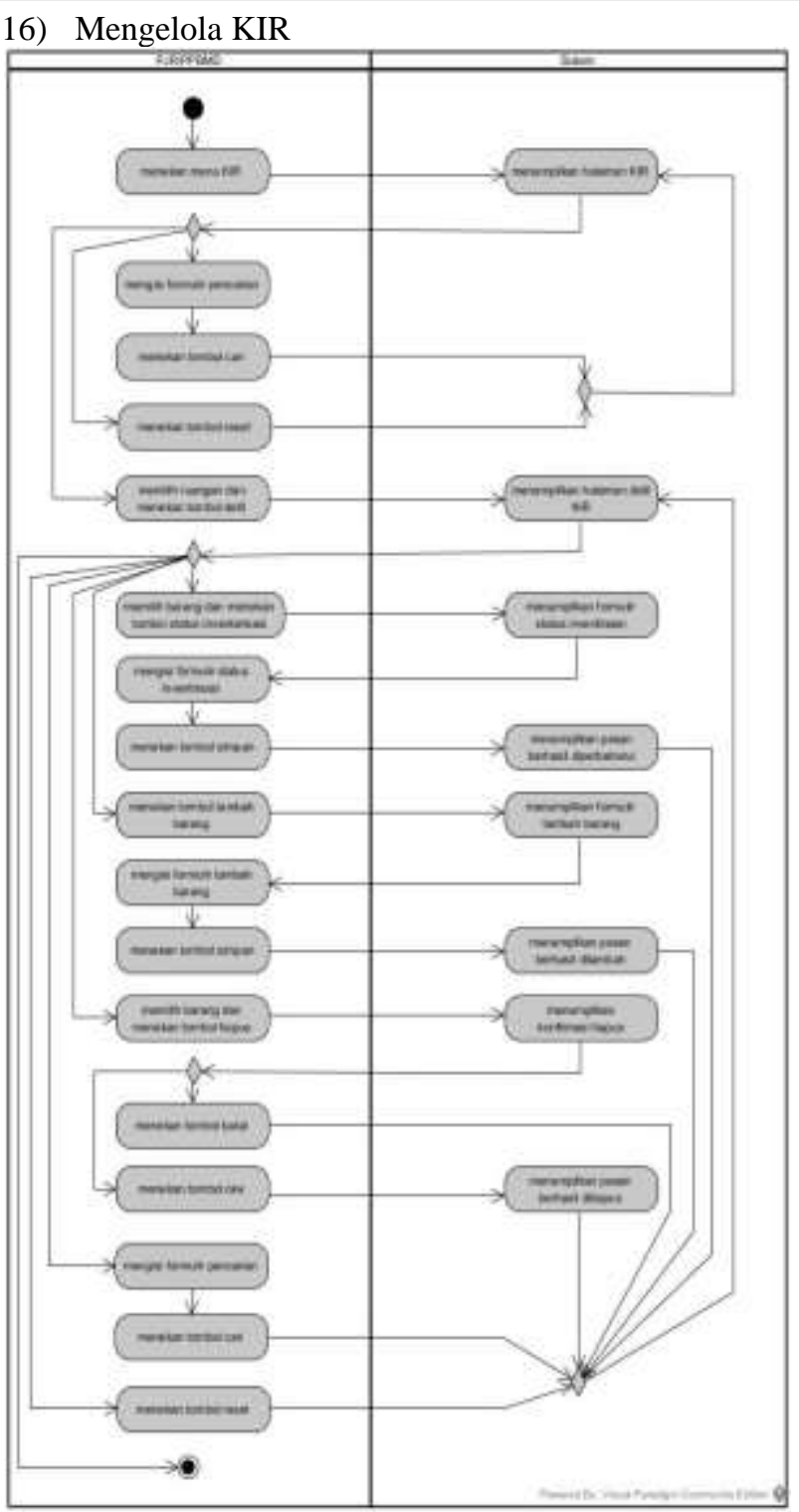

Gambar 18 : Swimlane diagram mengelola KIR

17) Mengelola Persetujuan KIR

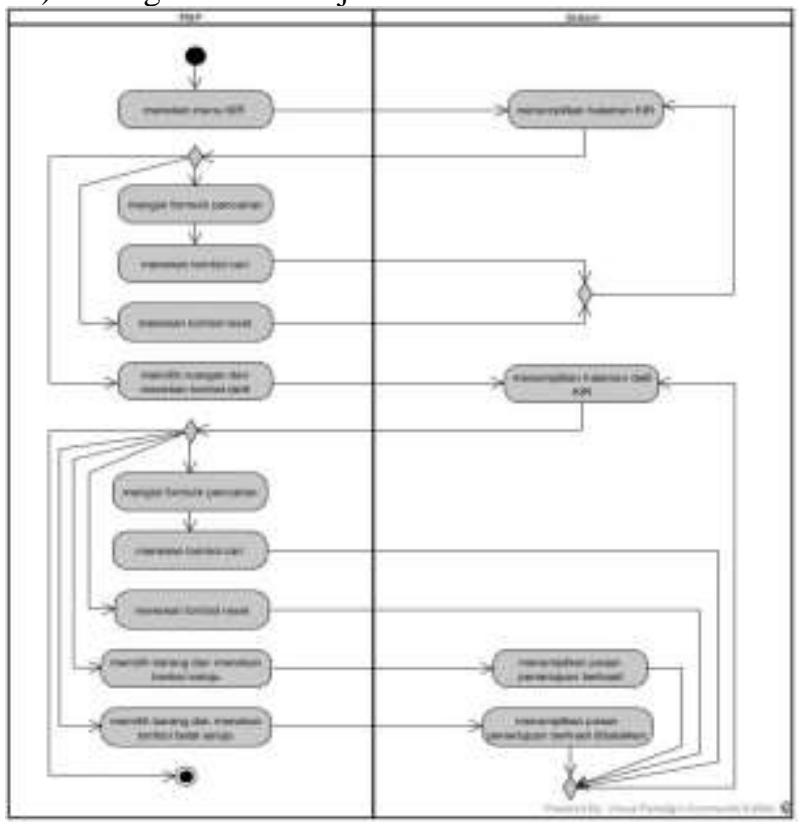

Gambar 19 : Swimlane diagram mengelola persetujuan KIR 
18) Mengelola Verifikasi KIR

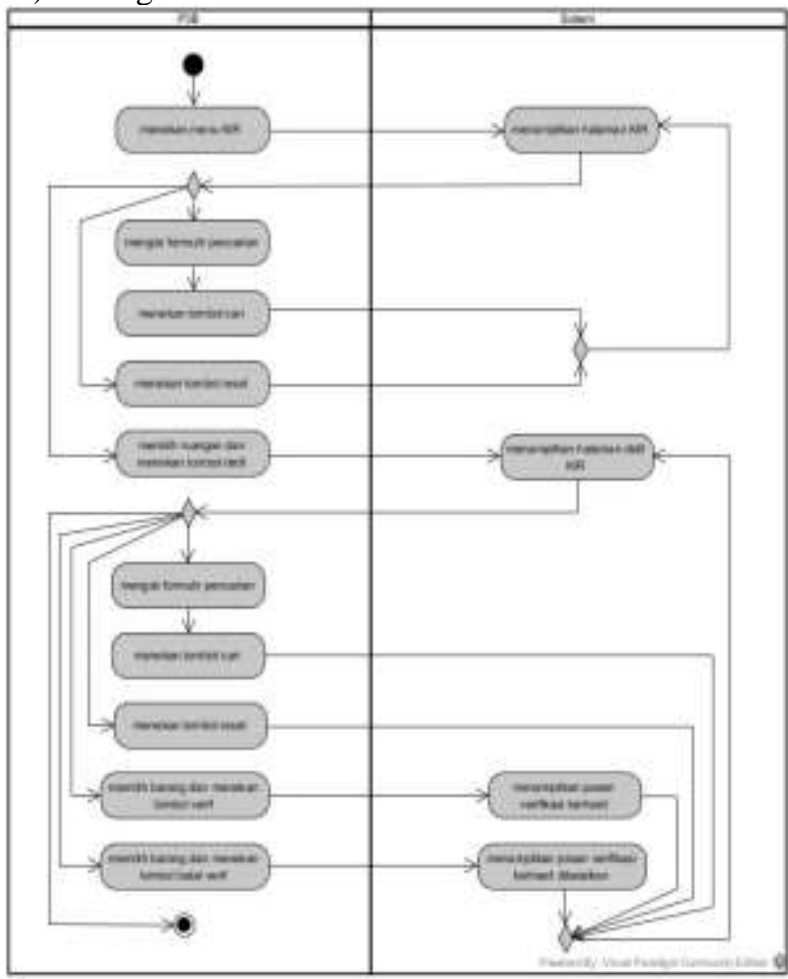

Gambar 20 : Swimlane diagram mengelola verifikasi KIR

19) Mengelola Laporan Inventarisasi

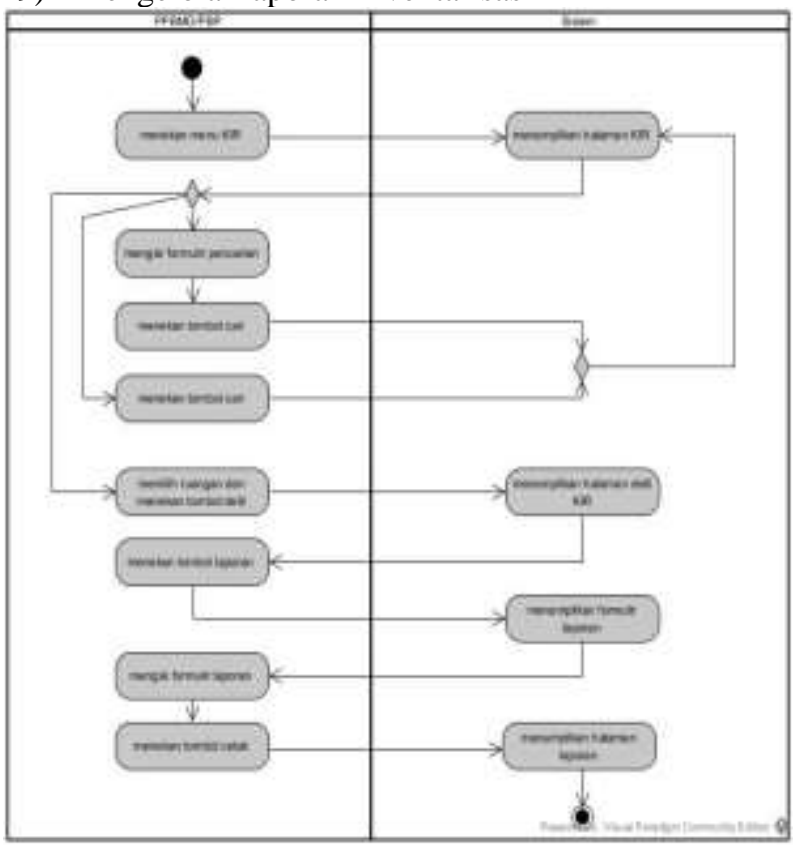

Gambar 21 : Swimlane diagram mengelola laporan inventarisasi
20) Melihat Rekap Inventarisasi

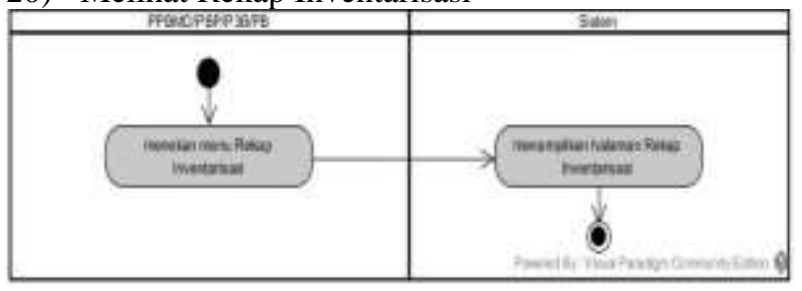

Gambar 22 : Swimlane diagram melihat rekap inventarisasi

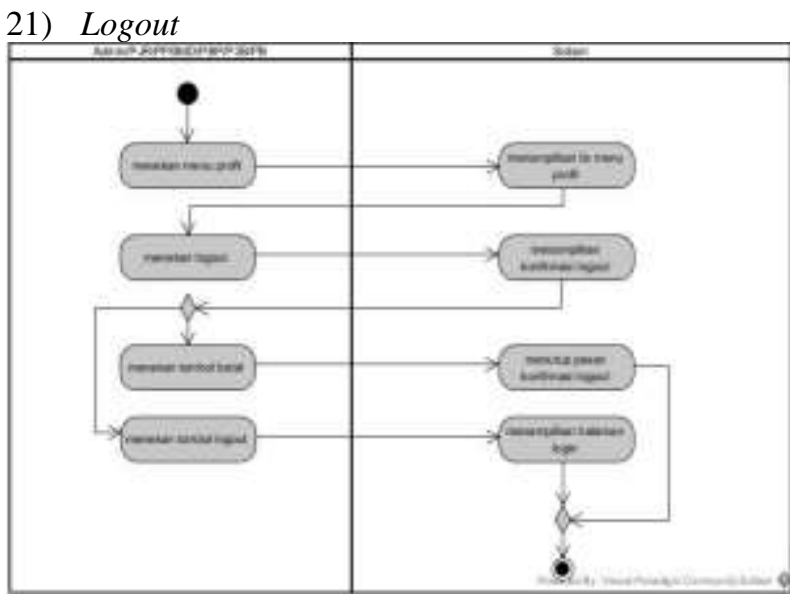

Gambar 23 : Swimlane Diagram Logout

\subsubsection{Class Diagram}

Class diagram menjelaskan hubungan setiap class yang ada pada Sistem Informasi Inventarisasi Peralatan dan Mesin. 


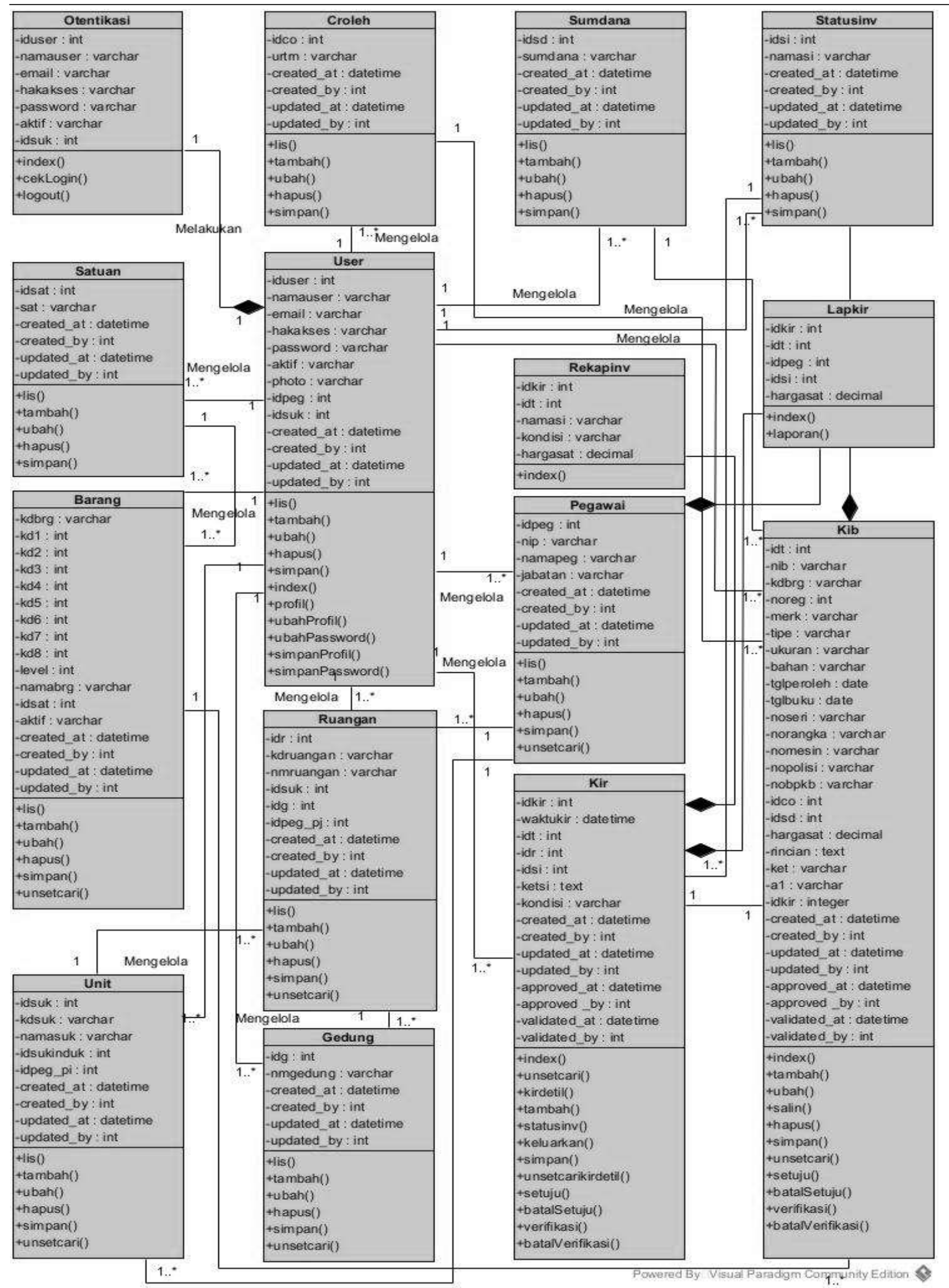

Gambar 24 : Class diagram SIIPAM 


\subsubsection{Entity Relationship Diagram}

Entity Relationship Diagram menjelaskan hubungan antar data dalam basis data berdasarkan objekobjek dasar data yang mempunyai hubungan antar relasi pada Sistem Informasi Inventarisasi Peralatan dan Mesin.

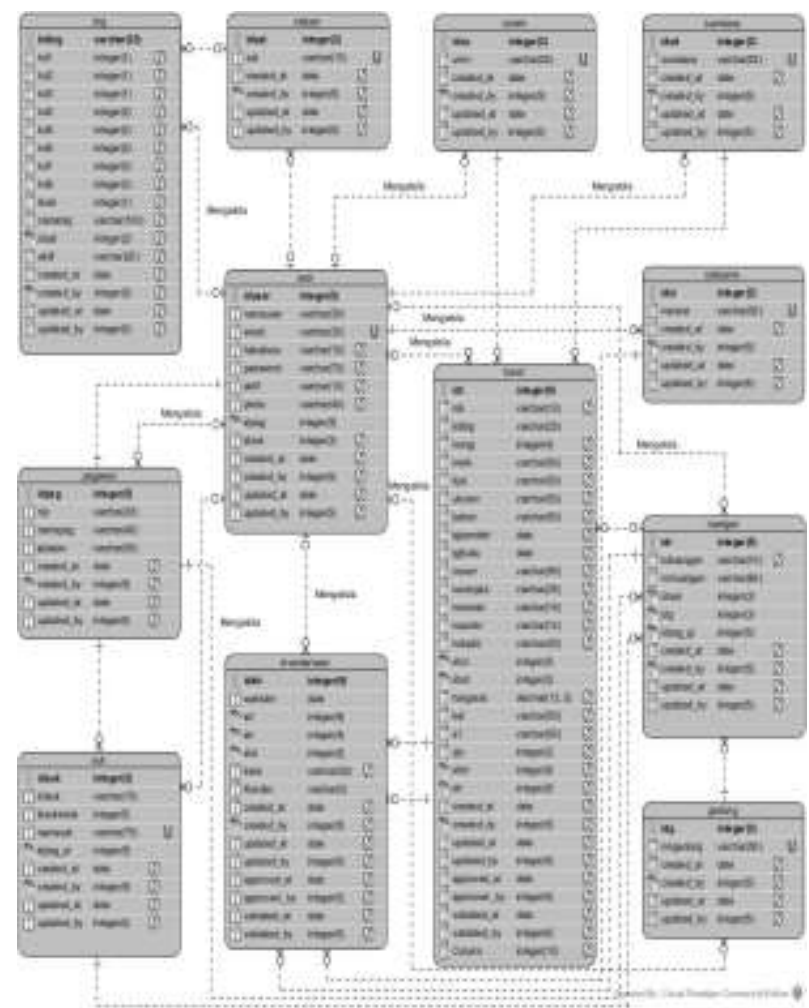

Gambar 25 : Entity relationship diagram SIIPAM

\section{PEMBAHASAN}

\subsection{Arsitektur Pembangunan Aplikasi}

Berikut adalah arsitektur pembangunan Sistem Informasi Inventarisasi Peralatan dan Mesin di RSUD Sayang Kabupaten Cianjur menggunakan konsep MVC (Model, View dan Controller), yaitu :

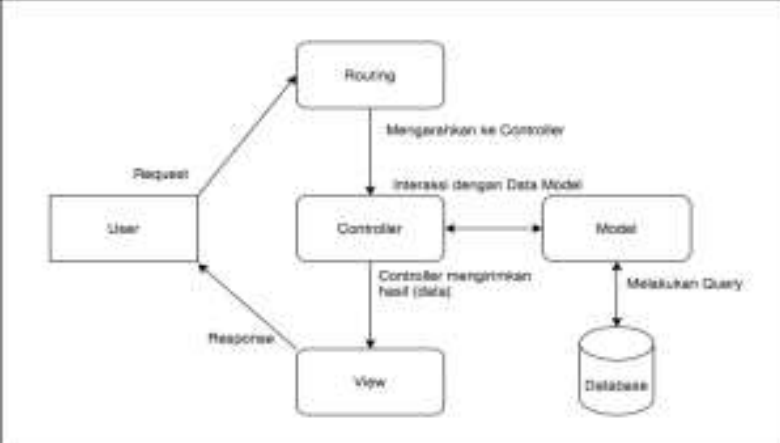

Gambar 26 : Arsitektur Pembangunan Aplikasi

User melakukan request ditangani oleh routes mengarahkan ke controller. Controller melakukan interaksi dengan model. Model melakukan query ke database dan mengirimkan kembali ke controller. Controller mengirimkan hasil (data) ke view. View memetakan tampilan untuk memberikan response kepada user.

\subsection{Implementasi Antar Muka}

Implementasi antar muka merupakan proses lanjutan dari hasil analisis dan perancangan yang telah dilakukan sebelumnya, pada pemrograman dengan menggunakan framework bootstrap untuk membuat antar muka, sebagai berikut :

\section{Halaman Login}

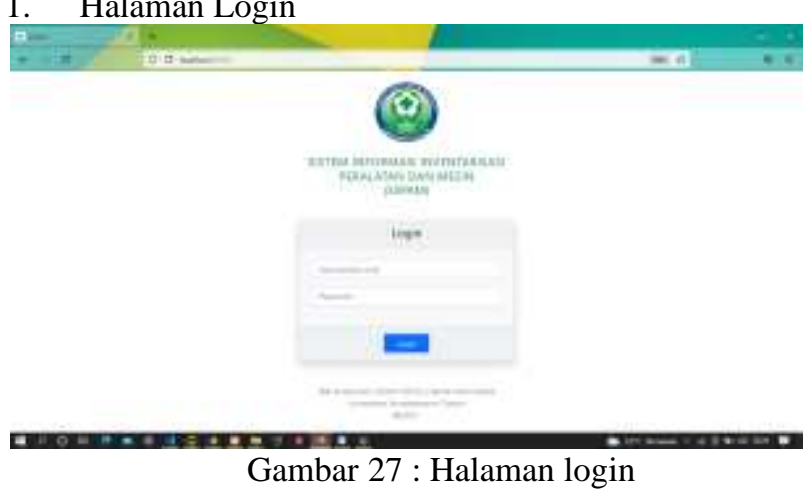

\section{Halaman KIR}

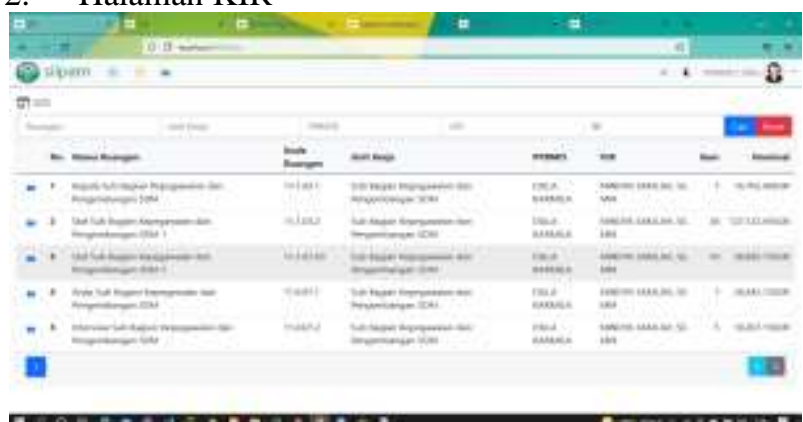

Gambar 28 : Halaman KIR

3. Halaman Detil KIR

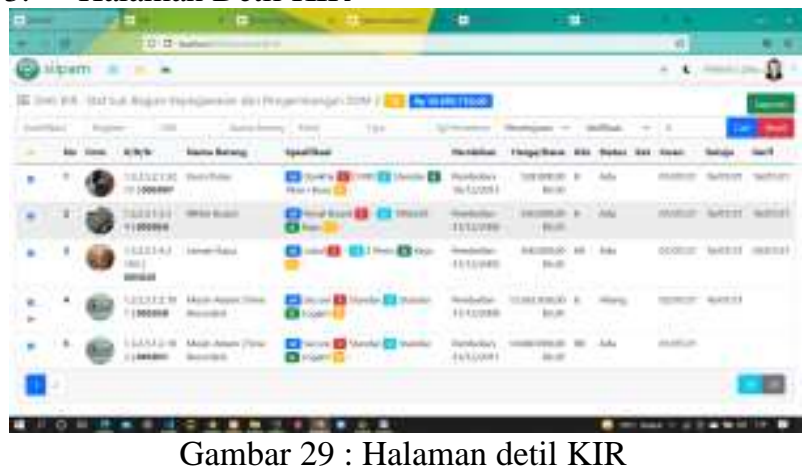

4. Halaman Status Inventarisasi

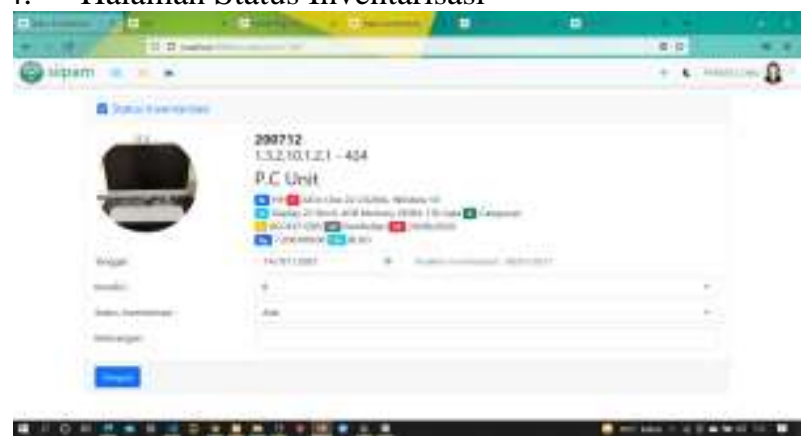

Gambar 30 : Halaman status inventarisasi 


\section{Halaman Tambah Barang dan Status Inventarisasi}

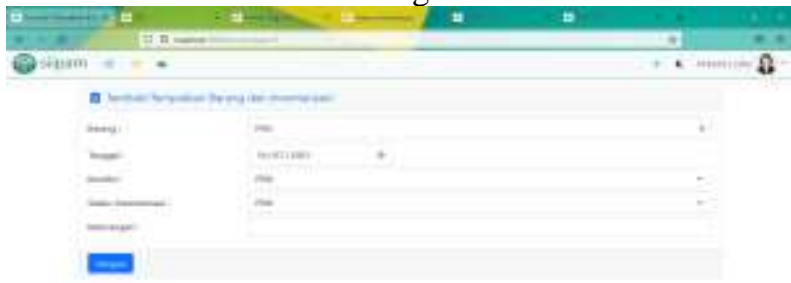

Gambar 31 : Halaman tambah barang dan status inventarisasi

6. Halaman Formulir Laporan Inventarisasi

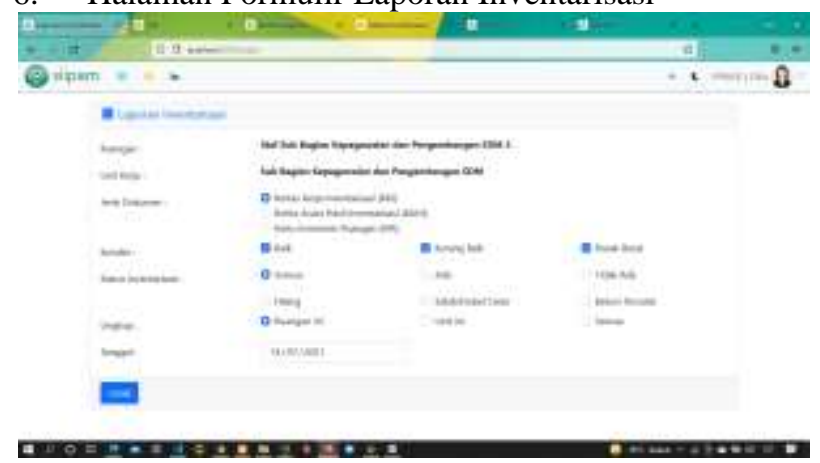

Gambar 32 : Halaman formulir laporan inventarisasi

7. Halaman Kertas Kerja Inventarisasi (KKI)

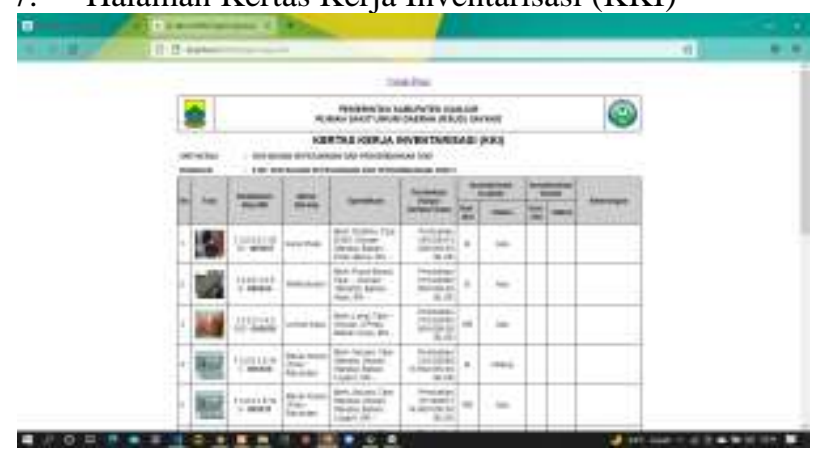

Gambar 33 : Halaman kertas kerja inventarisasi (KKI)

\section{Halaman Rekap Inventarisasi}

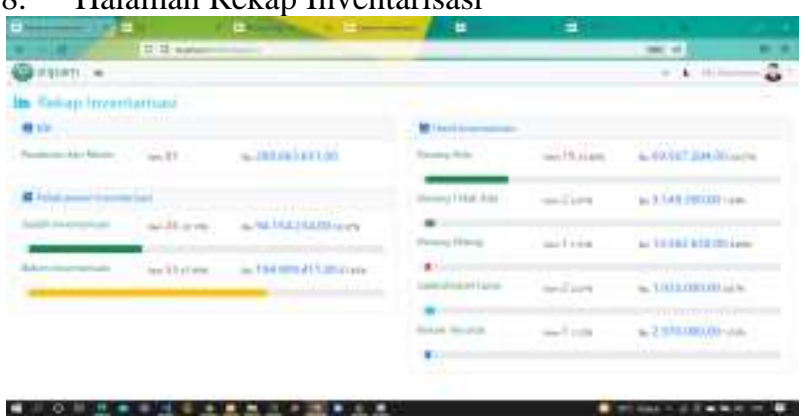

Gambar 34 : Halaman rekap inventarisasi

\subsection{Pengujian Sistem}

Pengujian sistem merupakan bagian yang paling penting dalam siklus pengembangan perangkat lunak. Pengujian dilakukan untuk menjamin kualitas dan juga mengetahui kelemahan dari perangkat lunak. Tujuan dari pengujian ini adalah untuk menjamin bahwa perangkat lunak yang dibangun memiliki kualitas yang handal. Pengujian perangkat lunak ini menggunakan metode black box yang dilakukan terhadap semua use case, sebagai berikut :

\begin{tabular}{|c|c|c|c|}
\hline No & $\begin{array}{c}\text { Skenario } \\
\text { Pengujian } \\
\text { (Input) }\end{array}$ & $\begin{array}{c}\text { Hasil yang } \\
\text { Diharapkan } \\
\text { (Output) }\end{array}$ & $\begin{array}{c}\text { Hasil } \\
\text { Pengujian }\end{array}$ \\
\hline 1 & $\begin{array}{l}\text { Aktor tidak } \\
\text { mengisi username } \\
\text { dan/atau password } \\
\text { kemudian } \\
\text { menekan tombol } \\
\text { login }\end{array}$ & $\begin{array}{l}\text { Sistem akan } \\
\text { menolak dan } \\
\text { menampilkan } \\
\text { pesan"Harus } \\
\text { diisi". }\end{array}$ & Sesuai \\
\hline 2 & $\begin{array}{lr}\text { Aktor } & \text { mengisi } \\
\text { username } & \text { dan/atau } \\
\text { password } & \text { salah } \\
\text { kemudian } & \\
\text { menekan } & \text { tombol } \\
\text { login } & \\
\end{array}$ & $\begin{array}{l}\text { Sistem akan } \\
\text { menolak dan } \\
\text { menampilkan } \\
\text { pesan"Maaf akun } \\
\text { belum terdaftar". }\end{array}$ & Sesuai \\
\hline 3 & $\begin{array}{lr}\text { Aktor } & \text { mengisi } \\
\text { username } & \text { benar } \\
\text { dan password salah } \\
\text { kemudian } \\
\text { menekan tombol } \\
\text { login }\end{array}$ & $\begin{array}{l}\text { Sistem akan } \\
\text { menolak dan } \\
\text { menampilkan } \\
\text { pesan"Maaf, } \\
\text { password salah". }\end{array}$ & Sesuai \\
\hline 4 & $\begin{array}{lr}\text { Aktor } & \text { mengisi } \\
\text { username } & \text { dan } \\
\text { password } & \text { benar } \\
\text { kemudian } & \\
\text { menekan tombol } \\
\text { login, tetapi status } \\
\text { akun sedang tidak } \\
\text { aktif }\end{array}$ & $\begin{array}{l}\text { Maaf, akun } \\
\text { tidakaktif. Silahka } \\
\text { n hubungi admin ! }\end{array}$ & Sesuai \\
\hline 5 & 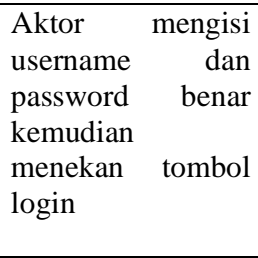 & $\begin{array}{l}\text { Sistem menerima } \\
\text { akses login dan } \\
\text { kemudian } \\
\text { menampilkan } \\
\text { halaman utama } \\
\text { user sesuai hak } \\
\text { akses }\end{array}$ & Sesuai \\
\hline 6 & $\begin{array}{l}\text { Aktor langsung } \\
\text { mengakses URL } \\
\text { halaman tertentu } \\
\text { tanpa login }\end{array}$ & $\begin{array}{l}\text { Sistem menolak } \\
\text { dan kemudian } \\
\text { menampilkan } \\
\text { halaman login }\end{array}$ & Sesuai \\
\hline
\end{tabular}
TABEL 3 : Pengujian Login

\begin{tabular}{|l|l|l|l|}
\hline No & \multicolumn{1}{|c|}{$\begin{array}{c}\text { Skenario } \\
\text { Pengujian } \\
\text { (Input) }\end{array}$} & \multicolumn{1}{|c|}{$\begin{array}{c}\text { Hasil yang } \\
\text { Diharapkan } \\
\text { (Output) }\end{array}$} & $\begin{array}{c}\text { Hasil } \\
\text { Pengujian }\end{array}$ \\
\hline 1 & $\begin{array}{l}\text { Aktor PPBMD } \\
\text { menekan menu } \\
\text { KIR }\end{array}$ & $\begin{array}{l}\text { Sistem } \\
\text { menampilkan } \\
\text { halaman KIR }\end{array}$ & Sesuai \\
\hline 2 & $\begin{array}{l}\text { Pada halaman } \\
\text { KIR, aktor } \\
\text { PPBMD mengisi } \\
\text { formulir pencarian } \\
\text { kemudian } \\
\text { menekan tombol } \\
\text { cari }\end{array}$ & $\begin{array}{l}\text { Sistem } \\
\text { menampilkan } \\
\text { halaman KIR } \\
\text { sesuai pencarian } \\
\text { dan formulir } \\
\text { pencarian terisi } \\
\text { sesuai kata kunci. }\end{array}$ & \\
\hline 3 & $\begin{array}{l}\text { Pada halaman } \\
\text { KIR, aktor } \\
\text { PPBMD menekan } \\
\text { tombol reset }\end{array}$ & $\begin{array}{l}\text { Sistem } \\
\text { menampilkan } \\
\text { halaman KIR dan } \\
\text { formulir pencarian } \\
\text { kosong. }\end{array}$ & \\
\hline 4 & $\begin{array}{l}\text { Pada halaman } \\
\text { KIR, aktor } \\
\text { PPBMD memilih } \\
\text { dan menan } \\
\text { tombol detil }\end{array}$ & $\begin{array}{l}\text { Sistem } \\
\text { menampilkan } \\
\text { halaman detil KIR } \\
\text { dengan tombol } \\
\text { tambah, status }\end{array}$ & \\
\hline
\end{tabular}


Nama Penulis, Judul Artikel

\begin{tabular}{|c|c|c|c|c|c|c|c|}
\hline No & $\begin{array}{c}\text { Skenario } \\
\text { Pengujian } \\
\text { (Input) }\end{array}$ & $\begin{array}{c}\text { Hasil yang } \\
\text { Diharapkan } \\
\text { (Output) } \\
\end{array}$ & $\begin{array}{c}\text { Hasil } \\
\text { Pengujian }\end{array}$ & No & $\begin{array}{c}\text { Skenario } \\
\text { Pengujian } \\
\text { (Input) }\end{array}$ & $\begin{array}{c}\text { Hasil yang } \\
\text { Diharapkan } \\
(\text { Output }) \\
\end{array}$ & $\begin{array}{c}\text { Hasil } \\
\text { Pengujian }\end{array}$ \\
\hline & & $\begin{array}{l}\text { inventarisasi dan } \\
\text { hapus/keluarkan. }\end{array}$ & & & \multirow{2}{*}{$\begin{array}{l}\text { tombol } \\
\text { hapus/keluarkan } \\
\text { (muncul jika sudah } \\
\text { disetujui dan status } \\
\text { tidak ada/ hilang/ } \\
\text { salah catat) }\end{array}$} & \multirow{2}{*}{$\begin{array}{l}\text { hapus/keluarkan } \\
\text { barang? } \\
\text { [menampilkan } \\
\text { data barang] }\end{array}$} & \\
\hline \multirow[t]{2}{*}{5} & \multirow{2}{*}{\begin{tabular}{l}
\multicolumn{2}{l}{ Pada halaman detil } \\
KIR, aktor \\
PPBMD mengisi \\
formulir pencarian \\
kemudian \\
menekan tombol \\
cari
\end{tabular}} & \multirow{2}{*}{$\begin{array}{l}\text { Sistem } \\
\text { menampilkan } \\
\text { halaman detil KIR } \\
\text { sesuai pencarian } \\
\text { dan formulir } \\
\text { pencarian terisi } \\
\text { sesuai kata kunci. }\end{array}$} & \multirow[t]{2}{*}{ Sesuai } & & & & \\
\hline & & & & \multirow[t]{2}{*}{14} & \multirow{2}{*}{$\begin{array}{lr}\text { Pada } & \text { konfirmasi } \\
\text { hapus, } & \text { aktor } \\
\text { PPBMD menekan } \\
\text { tombol batal }\end{array}$} & \multirow[t]{2}{*}{$\begin{array}{l}\text { Sistem kembali } \\
\text { menampilkan } \\
\text { halaman detil KIR }\end{array}$} & \multirow[t]{2}{*}{ Sesuai } \\
\hline \multirow[t]{2}{*}{6} & Pada halaman detil & Sistem & Sesuai & & & & \\
\hline & $\begin{array}{l}\text { KIR, aktor } \\
\text { PPBMD menekan } \\
\text { tombol reset }\end{array}$ & $\begin{array}{l}\text { menampilkan } \\
\text { halaman KIR dan } \\
\text { formulir pencarian } \\
\text { kosong. }\end{array}$ & & \multirow[t]{2}{*}{15} & \multirow[t]{2}{*}{$\begin{array}{l}\text { Pada konfirmasi } \\
\text { hapus, aktor } \\
\text { PPBMD menekan } \\
\text { tombol oke }\end{array}$} & \multirow{2}{*}{$\begin{array}{l}\text { Sistem } \\
\text { mengosongkan } \\
\text { data ID Ruangan } \\
\text { kemudian } \\
\text { menampilkan } \\
\text { halaman detil KIR } \\
\text { dan pesan } \\
\text { "Berhasil dikeluarkan". }\end{array}$} & \multirow[t]{2}{*}{ Sesuai } \\
\hline 7 & $\begin{array}{l}\text { Pada halaman detil } \\
\text { KIR, aktor } \\
\text { PPBMD menekan } \\
\text { tombol tambah }\end{array}$ & $\begin{array}{l}\text { Sistem } \\
\text { menampilkan } \\
\text { halaman tambah } \\
\text { barang dan } \\
\text { inventarisasi }\end{array}$ & Sesuai & & & & \\
\hline \multirow[t]{3}{*}{8} & \multirow{3}{*}{$\begin{array}{l}\text { Pada halaman } \\
\text { tambah barang dan } \\
\text { inventarisasi, aktor } \\
\text { PPBMD tidak } \\
\text { mengisi formulir } \\
\text { yang harus diisi } \\
\text { kemudian } \\
\text { menekan tombol } \\
\text { simpan }\end{array}$} & \multirow[t]{3}{*}{$\begin{array}{l}\text { Sistem menolak } \\
\text { dan menampilkan } \\
\text { pesan "Harus diisi } \\
\text { / Pilih salah satu } \\
\text { item pada daftar" }\end{array}$} & \multirow[t]{3}{*}{ Sesuai } & 16 & $\begin{array}{lr}\text { Aktor } & \text { selain } \\
\text { PPBMD dan PBP } & \text { mengakses } \\
\text { URL } \\
\text { halaman } & \text { index/ } \\
\text { tambah/ } & \text { ubah/ } \\
\text { hapus KIR } & \\
\end{array}$ & $\begin{array}{l}\text { Sistem menolak } \\
\text { dan menampilkan } \\
\text { kembali halaman } \\
\text { sebelumnya }\end{array}$ & Sesuai \\
\hline & & & & \multicolumn{4}{|c|}{ TABEL 4 : Pengujian Mengelola KIR } \\
\hline & & & & \multirow[b]{2}{*}{ No } & \multirow{2}{*}{$\begin{array}{c}\text { Skenario } \\
\text { Pengujian } \\
\text { (Input) }\end{array}$} & \multirow{2}{*}{$\begin{array}{c}\text { Hasil yang } \\
\text { Diharapkan } \\
\text { (Output) }\end{array}$} & \multirow[b]{2}{*}{$\begin{array}{c}\text { Hasil } \\
\text { Pengujian }\end{array}$} \\
\hline \multirow[t]{3}{*}{9} & \multirow{3}{*}{$\begin{array}{l}\text { Pada halaman } \\
\text { tambah barang dan } \\
\text { inventarisasi, aktor } \\
\text { PPBMD mengisi } \\
\text { formulir dengan } \\
\text { benar kemudian } \\
\text { menekan tombol } \\
\text { simpan }\end{array}$} & \multirow{3}{*}{$\begin{array}{l}\text { Sistem } \\
\text { menampilkan } \\
\text { halaman detil KIR } \\
\text { dan pesan } \\
\text { "Berhasil } \\
\text { ditambah" }\end{array}$} & \multirow[t]{3}{*}{ Sesuai } & & & & \\
\hline & & & & 1 & $\begin{array}{l}\text { Aktor } \\
\text { PPBMD/PBP } \\
\text { menekan menu } \\
\text { KIR }\end{array}$ & $\begin{array}{l}\text { Sistem } \\
\text { menampilkan } \\
\text { halaman KIR }\end{array}$ & Sesuai \\
\hline & & & & \multirow[t]{2}{*}{2} & \multirow{2}{*}{$\begin{array}{lr}\text { Pada } & \text { halaman } \\
\text { KIR, aktor } \\
\text { PPBMD/PBP } \\
\text { mengisi formulir } \\
\text { pencarian } \\
\text { kemudian } \\
\text { menekan tombol } \\
\text { cari }\end{array}$} & \multirow{2}{*}{$\begin{array}{l}l \\
\text { Sistem } \\
\text { menampilkan } \\
\text { halaman KIR } \\
\text { sesuai pencarian } \\
\text { dan formulir } \\
\text { pencarian terisi } \\
\text { sesuai kata kunci. }\end{array}$} & \multirow[t]{2}{*}{ Sesuai } \\
\hline 10 & \begin{tabular}{lr}
\multicolumn{2}{l}{ Pada halaman detil } \\
KIR, aktor \\
PPBMD & memilih \\
dan ranekan & menekan \\
tombol $r$ & status \\
inventarisasi
\end{tabular} & $\begin{array}{l}\text { Sistem } \\
\text { menampilkan } \\
\text { halaman status } \\
\text { inventarisasi dan } \\
\text { formulir sudah } \\
\text { terisi sesuai status }\end{array}$ & Sesuai & & & & \\
\hline \multirow{3}{*}{11} & \multirow{3}{*}{$\begin{array}{l}\text { Pada halaman } \\
\text { status } \\
\text { inventarisasi, aktor } \\
\text { PPBMD } \\
\text { mengosongkan isi } \\
\text { formulir yang } \\
\text { harus } \\
\text { kemudian diisi } \\
\text { menekan tombol } \\
\text { simpan }\end{array}$} & \multirow{3}{*}{$\begin{array}{l}\text { Sistem menolak } \\
\text { dan menampilkan } \\
\text { pesan "Harus diisi/ } \\
\text { Pilih salah satu } \\
\text { item pada daftar" }\end{array}$} & & 3 & Pada halaman & Sistem & Sesuai \\
\hline & & & Sesuai & & $\begin{array}{l}\text { KIR, aktor } \\
\text { PPBMD/PBP } \\
\text { menekan tombol } \\
\text { reset }\end{array}$ & $\begin{array}{l}\text { menampilkan } \\
\text { halaman KIR dan } \\
\text { formulir pencarian } \\
\text { kosong. }\end{array}$ & \\
\hline & & & & 4 & $\begin{array}{lr}\text { Pada } & \text { halaman } \\
\text { KIR, aktor } \\
\text { PPBMD/PBP } \\
\text { memilih dan } \\
\begin{array}{l}\text { menekan tombol } \\
\text { detil }\end{array}\end{array}$ & $\begin{array}{l}\text { Sistem } \\
\text { menampilkan } \\
\text { halaman detil KIR } \\
\text { (disertai tombol } \\
\text { sesuai hak akses) }\end{array}$ & Sesuai \\
\hline 12 & $\begin{array}{l}\text { Pada halaman } \\
\text { status } \\
\text { inventarisasi, aktor } \\
\text { PPBMD } \\
\text { mengubah isi }\end{array}$ & $\begin{array}{l}\text { Sistem } \\
\text { menampilkan } \\
\text { halaman detil KIR } \\
\text { dan "Berhasil pesan } \\
\text { "Bly }\end{array}$ & Sesuai & 5 & $\begin{array}{l}\text { Pada halaman } \\
\text { KIR, aktor } \\
\text { PPBMD/PBP } \\
\text { menekan tombol } \\
\text { laporan }\end{array}$ & $\begin{array}{l}\text { Sistem } \\
\text { menampilkan } \\
\text { halaman formulir } \\
\text { laporan }\end{array}$ & Sesuai \\
\hline & $\begin{array}{l}\text { formulir dengan } \\
\text { benar kemudian } \\
\text { menekan tombol } \\
\text { simpan }\end{array}$ & diperbaharui" & & 6 & $\begin{array}{l}\text { Pada halaman } \\
\text { formulir laporan, } \\
\text { aktor } \\
\text { PPBMD/PBP }\end{array}$ & $\begin{array}{l}\text { Sistem } \\
\text { menampilkan } \\
\text { halaman kertas } \\
\text { kerja inventarisasi }\end{array}$ & Sesuai \\
\hline 13 & \begin{tabular}{lr}
\multicolumn{2}{l}{ Pada halaman detil } \\
KIR, & aktor \\
PPBMD & memilih \\
dan & menekan \\
\end{tabular} & $\begin{array}{l}\text { Sistem } \\
\text { menampilkan } \\
\text { konfirmasi } \\
\begin{array}{ll}\text { "Yakin } & \text { hapus } \\
\end{array}\end{array}$ & Sesuai & & $\begin{array}{l}\text { mengisi formulir } \\
\text { dan memlilih jenis } \\
\text { dokumen kertas } \\
\text { kerja inventarisasi }\end{array}$ & & \\
\hline
\end{tabular}




\begin{tabular}{|c|c|c|c|}
\hline No & $\begin{array}{l}\text { Skenario } \\
\text { Pengujian } \\
\text { (Input) }\end{array}$ & $\begin{array}{l}\text { Hasil yang } \\
\text { Diharapkan } \\
\text { (Output) }\end{array}$ & $\begin{array}{c}\text { Hasil } \\
\text { Pengujian }\end{array}$ \\
\hline & $\begin{array}{l}\text { kemudian } \\
\text { menekan tombol } \\
\text { cetak }\end{array}$ & & \\
\hline 7 & $\begin{array}{l}\text { Pada halaman } \\
\text { formulir laporan, } \\
\text { aktor } \\
\text { PPBMD/PBP } \\
\text { mengisi formulir } \\
\text { dan memlilih jenis } \\
\text { dokumen berita } \\
\text { acara hasil } \\
\text { inventarisasi } \\
\text { kemudian } \\
\text { menekan tombol } \\
\text { cetak }\end{array}$ & $\begin{array}{l}\text { Sistem } \\
\text { menampilkan } \\
\text { halaman berita } \\
\begin{array}{lr}\text { acara hasil } \\
\text { inventarisasi }\end{array}\end{array}$ & Sesuai \\
\hline 8 & $\begin{array}{l}\text { Pada halaman } \\
\text { formulir laporan, } \\
\text { aktor } \\
\text { PPBMD/PBP } \\
\text { mengisi formulir } \\
\text { dan memlilih jenis } \\
\text { dokumen kartu } \\
\text { inventaris ruangan } \\
\text { kemudian } \\
\text { menekan tombol } \\
\text { cetak }\end{array}$ & $\begin{array}{l}\text { Sistem } \\
\text { menampilkan } \\
\text { halaman kartu } \\
\text { inventaris ruangan }\end{array}$ & Sesuai \\
\hline
\end{tabular}

TABEL 5 : Pengujian Mengelola Laporan

\begin{tabular}{|l|l|l|l|}
\hline No & \multicolumn{1}{|c|}{$\begin{array}{c}\text { Skenario } \\
\text { Pengujian } \\
\text { (Input })\end{array}$} & \multicolumn{1}{|c|}{$\begin{array}{c}\text { Hasil yang } \\
\text { Diharapkan } \\
(\text { Output })\end{array}$} & $\begin{array}{c}\text { Hasil } \\
\text { Pengujian }\end{array}$ \\
\hline 1 & $\begin{array}{l}\text { Aktor } \\
\text { PPBMD/PBP/PB } \\
\text { menekan menu } \\
\text { Rekap }\end{array}$ & $\begin{array}{l}\text { Sistem } \\
\text { menampilkan } \\
\text { halaman rekap } \\
\text { inventarisasi }\end{array}$ & Sesuai \\
\hline 2 & $\begin{array}{l}\text { Aktor selain } \\
\text { PPBMD/PBP/PB } \\
\text { mengakses URL } \\
\text { halaman rekap }\end{array}$ & $\begin{array}{l}\text { Sistem menolak } \\
\text { dan menampilkan } \\
\text { kembali halaman } \\
\text { sebelumnya }\end{array}$ & Sesuai \\
\hline
\end{tabular}

[4] Walikota Probolinggo, "Peraturan Walikota Probolinggo Nomor 74 Tahun 2018 tentang Petunjuk Teknis Inventarisasi Barang Milik Daerah," vol. 2007. Sekretariat Daerah Kota Probolinggo, Probolinggo, pp. 1-101, 2017.

[5] M. A. Lubis, I. Murni, and Arfansyah, "Pengaruh Penerapan Sistem Informasi Pemeliharaan Peralatan Dan Mesin Kantor Pada Efisiensi," J. Edik Inform., vol. 3, no. 1, pp. 8-17, 2017.

\subsection{Deployment}

Deployment merupakan bagian terakhir dalam siklus pengembangan perangkat lunak. Deployment adalah kegiatan yang bertujuan untuk menyebarkan aplikasi yang telah dikerjakan oleh pengembang kepada pengguna. Strategi deployment yang digunakan yaitu Blue /Green Deployment. Konsepnya cukup sederhana, yaitu, membuat satu environment yang serupa dengan yang sedang aktif/live, kemudian melakukan switching request ke environment baru tersebut. Sistem informasi inventarisasi peralatan dan mesin diinstall pada komputer server, dihubungkan ke jaringan LAN dan internet sehingga dapat diakses secara lokal maupun online oleh para pengguna pada RSUD Sayang.

[6] A. Mujilan, Analisis dan Perancangan Sistem Perspektif Bidang Akuntansi, 1st ed. Madiun: Fakultas Ekonomi dan Bisnis Universitas Katolik Widya Mandala, 2017.

[7] F. Nurpandi, A. Musrifah, and I. Rizaldi, "Prototype Residence Monitoring and Automation System Using Microcontroller Arduino," Proceeding - 2018 Int. Conf. ICT Smart Soc. Innov. Towar. Smart Soc. Soc. 5.0, ICISS 2018, pp. 2-6, 2018.

[8] Pressman \& S R, Rekayasa Perangkat Lunak: Pendekatan Praktisi Edisi 7. Yogyakarta: Andi, 2010. 